\title{
Las imprentas, el liberalismo radical y comunicación con espíritus: divulgación de las doctrinas espiritistas en Colombia (1868-1889)*
}

\section{Resumen}

Este artículo estudia las prácticas espiritistas en Colombia durante la segunda mitad del siglo XIX como un acto de resistencia a la Iglesia católica. Esto en un contexto de romanización de la Iglesia católica que puso en riesgo a quienes fueran disidentes políticos y religiosos como los espiritistas. El análisis de los documentos para una historia del espiritismo en Colombia entre 1868 y 1889 se efectuó reconociendo en esta disidencia religiosa ideas universales como las de igualdad, fraternidad, libertad anticlericalismo, laicización del Estado y la defensa de valores como la libertad de cultos. La investigación pudo evidenciar que en ciudades como Bogotá y Medellín el espiritismo tuvo una amplia difusión en los círculos de artesanos y de nuevos burgueses que en el siglo XIX se relacionaron principalmente con el liberalismo del ala radical, con el mundo de la imprentas y con el desarrollo artístico y cultural colombiano de ese periodo.

\section{Palabras clave}

Tesauro: espiritualismo, catolicismo, práctica religiosa, intelectuales, élite cultural, liberalismo, imprenta.

Referencia bibliográfica para citar este artículo: Mancera Rodríguez, Ana María. "Las imprentas, el liberalismo radical y comunicación con espíritus: divulgación de las doctrinas espiritistas en Colombia (1868-1889)". Anuario de Historia Regional y de las Fronteras, 25.1 (2019): 135-172.

Ana María Mancera Rodríguez: Historiadora de la Pontificia Universidad Javeriana (Bogotá). Código ORCID: 0000-0001-8179-9974. Correo electrónico: mancera.a@javeriana.edu.co

\footnotetext{
* La propuesta aquí presentada se deriva de la investigación para la elaboración del proyecto de grado en historia. Experiencia laboral en los campos de la investigación histórica y de la creación y manejo de bases de datos para el grupo de Arqueología y el de Patrimonio del Instituto colombiano de Antropología e Historia (ICANH), relacionados con fundaciones de ciudades coloniales de la red de municipios patrimonio en Colombia, y la creación y protección del Patrimonio arqueológico en Colombia, mediante el establecimiento de los Parques Arqueológicos. Intereses personales en historia de la brujería, historia del espiritismo, historia de la moda, historia del arte e historia de la antropología.
} 


\title{
Printing press, radical liberalism and communication with spirits: dissemination of spiritualist doctrines in Colombia (1868-1889)
}

\begin{abstract}
This article studies spiritualistic practices in Colombia during the second half of the nineteenth century as an act of resistance to the Catholic Church. It is framed in a context of Romanization of the Catholic Church which put at risk those who were political and religious dissidents such as spiritualists. The analysis of the documents for a history of spiritualism in Colombia between 1868 and 1889 was carried out recognizing in this religious dissent universal ideas such as equality, fraternity, anticlerical freedom, secularization of the state and the defense of values such as freedom of worship. The research showed that in cities such Bogotá and Medellin, spiritualism had a wide diffusion in the circles of artisans and new bourgeois who in the nineteenth century were mainly related to the liberalism of the radical wing, along with the world of printing press and the Colombian artistic and cultural development of that period.
\end{abstract}

Keywords

Tesauro: spiritualism, Catholicism, religious practice, intellectuals, cultural elite, liberalism, printing.

\section{Prensas móveis, liberalismo radical e comunicação com os espíritos: disseminação de doutrinas espíritas na Colômbia (1868-1889)}

Resumo

Este artigo estuda as práticas espíritas na Colômbia durante a segunda metade do século XIX, como um ato de resistência à Igreja Católica. Enquadrado em um contexto de romanização da Igreja Católica que colocou em risco qualquer dissidente político e religiosos, como os espiritualistas. A análise dos documentos para uma história do espiritualismo na Colombia entre 1868 e 1889 foi realizada reconhecendo nesta dissidência religiosa ideias universais como igualdade, fraternidade, liberdade anticlerical, secularização do Estado e defesa de valores como a liberdade de culto. A pesquisa mostrou que em cidades como Bogotá e Medellín, o espiritualismo teve uma ampla difusão nos círculos de artesãos e da nova burguesia que no século XIX estavam principalmente relacionados ao liberalismo da ala radical, ao mundo das prensas móveis e aos desenvolvimento artístico e cultural colombiano desse período.

Palavras chave

Tesauro: espiritualismo, catolicismo, prática religiosa, intelectuais, elite cultural, liberalismo, prensa móvel. 


\section{Introducción}

El esoterismo, el ocultismo, la brujería y otras denominaciones sobre prácticas anticatólicas han sido malinterpretadas y han llegado a nuestros días como concepciones y reducciones vulgares de problemas históricos que influenciaron la política, la religiosidad, el arte y la espiritualidad en Colombia. Dentro de este espectro de creencias espirituales que aún se practican en Colombia figura el espiritismo. Aunque historiográficamente en Colombia, este tema ha sido escasamente estudiado, el historiador Gilberto Loaiza, en capítulos de libros y en artículos en los que menciona el tema del espiritismo ha afirmado que este llegó a Colombia a los círculos de artesanos y de liberales radicales, en los que se debatía el tema del cristianismo igualitario y del radicalismo popular. ${ }^{1}$

Este movimiento surgió en el contexto de la Industrialización del siglo XIX, de los valores de la Ilustración, de los avances de la ciencia y en medio de un mundo que se replanteaba la relación de los individuos con Dios. El espiritismo se basaba en tres cánones: el primero era la creencia en la existencia del alma; el segundo, la convicción de que los vivos podían comunicarse con los espíritus de los muertos; y, el tercero, la creencia en la reencarnación y en la evolución del alma. ${ }^{2}$

El objetivo de este artículo es argumentar que las prácticas espiritistas, siguiendo la tesis de De Certeau, estaba lejos de ser un consumo pasivo de teorías francesas sobre la reencarnación, de hecho, esas prácticas fueron una resistencia al sistema religioso del momento y al conservadurismo político de una forma tan fuerte que de ellas nos queda una fascinante producción de textos espiritistas publicados en Bogotá durante la segunda mitad del siglo XIX. Los espiritistas lejos de ser dominados o consumidores ciegos de las teorías espiritistas, fueron agrestes defensores de ideales como los de la revolución francesa, el anticlericalismo, la idea de universalizar la educación y también estuvieron a favor de la laicización del estado.

La hipótesis planteada es que quienes pertenecieron al círculo espiritista en ciudades como Bogotá y Medellín desde 1868 a 1889, se asociaron también por medio de las ideas políticas liberales de estas ciudades. El artículo demuestra que espiritistas como José Benito Gaitán, Rodolfo Cano y Melitón Rodríguez enfrentaron en términos generales a los postulados conservadores y católicos de gobiernos como el de Rafael Núñez, este hecho se relaciona con el caso del espiritista Francisco Ignacio Madero en México quien habiendo recibido mensajes de espíritus de liberales fallecidos ${ }^{3}$ se organizó para consolidar las ideas necesarias para el inicio a la oposición al gobierno de Porfirio Díaz que terminaría en la Revolución Mexicana.

\footnotetext{
${ }^{1}$ Gilberto Loaiza Cano, Cultura Popular en Poder letrado, ensayos sobre historia intelectual de Colombia Siglos XIX y XX. (Cali: Programa editorial Universidad del Valle, 2014), 92.

2 "Publicación dedicada a los colombianos por la Sociedad Espiritistas Americana-Sección Bogotá" 32 páginas. Tamaño 13 centímetros. BNC, Miscelánea José Asunción Silva, 424, Pieza 12. Disponible en formato digital http://catalogoenlinea.bibliotecanacional.gov.co/client/es_ES/search/asset/75043

${ }^{3}$ Enrique Krause, Francisco I. Madero. El místico de la libertad. (México D.F: Fondo de cultura económica, 1897), 19.
} 
Los espiritistas que se han identificado pertenecieron a esa nueva burguesía ${ }^{4}$ a la que hace referencia José Luis Romero en Latinoamérica, las ciudades y las ideas, ellos pudieron, o no, haber sido una clase de "esnobs" que influenciados por sus estancias en París o por su relación conocieron al espiritismo y condenaron al catolicismo y al conservadurismo político como los factores que habían sumido a las ciudades colombianas en la falta absoluta de progreso y modernidad. Medellín y Bogotá fueron en el siglo XIX tildadas de provincianas o coloniales por colombianos y extranjeros, estas urbes habían sufrido debido a la falta de los fenómenos que eran necesarios para su transformación y florecimiento como ciudades en el sentido europeo del concepto, pero estos burgueses, ilustrados, liberales y espiritistas aportarían sus ideas para que la lucha por el poder en Colombia se orientara a dejar atrás esos factores de atraso, la bandera que sostenían era la del espiritismo.

Esa nueva burguesía, a la que no solo pertenecían los espiritistas o los liberales, sino también los conservadores, depositó su fe en las ideas de progreso europeas. Esos burgueses, conservadores o liberales, herejes o católicos, pelearon por el poder y un ejemplo de ello es que, en este caso en el seno del liberalismo radical, donde se agruparon los espiritistas, hubo una clase de época dorada para ellos debida al gobierno del Olimpo Radical (1863-1886) y al establecimiento de la Constitución de Rionegro.

Uno de los conceptos que fueron esenciales en el contexto colombiano de la segunda mitad del siglo XIX, fue el de la Romanización de la Iglesia católica. Rodolfo de Roux, en La romanización de la Iglesia católica en América Latina: una estrategia de larga duración aclara que este proceso pretendió centralizar y unificar la institución católica según las directivas de la Curia romana, esto con el fín de integrar a los católicos en torno a la figura del papa, ${ }^{5}$ en un periodo de gobiernos liberales presentes en las nuevas naciones de América Latina, y también en Europa. Con esto se replantearon nociones sobre el significado del ser católico, sobre el actuar político de la Iglesia y la forma en la que esta institución se relacionó con los Estados del siglo XIX que estaban embriagados por las reinterpretaciones decimonónicas de la Revolución Francesa y de la Ilustración. Para lo anterior la Iglesia católica en Colombia se organizó institucionalmente mediante la fundación de nuevas diócesis y la realización de los primeros Concilios Provinciales (1868 y 1872). ${ }^{6}$

Desde el periodo del Olimpo Radical, hasta inicios del siglo XX la censura de la Iglesia católica contra el espiritismo puede probarse con casos específicos en los que, o bien, algún sacerdote censuró a un espiritista, o también, algunas diócesis publicaron pastorales y refutaciones al espiritismo, en las que acusaban a este cuerpo de doctrinas como brujería o comunicaciones con el demonio.

\footnotetext{
${ }^{4}$ José Luis Romero, Latinoamérica. Las ciudades y las ideas (Buenos Aires: Siglo xxi editores argentina, S. a, 2001), 284.

${ }^{5}$ Rodolfo R. de Roux, "La romanización de la Iglesia católica en América Latina: una estrategia de larga duración”, Pro-Posições 25, no. 1 (2014): 31.

${ }^{6}$ Jhon Janer Vega, "La Diócesis de San Pedro Apóstol de Nueva Pamplona: Una iniciativa de reorganización eclesiástica en la Iglesia colombiana durante el siglo XIX" Anuario de Historia Regional y de las Fronteras 16, no. 1 (2011): 102.
} 
Los primeros cinco años de la década de 1880 hubo enfrentamientos entre el radicalismo liberal y la llamada Regeneración, que fue la respuesta conservadora a las reformas liberales del Olimpo Radical. Debido al ascenso al poder de Rafael Núñez y a la instauración de la Constitución de 1886, los conservadores dominaron políticamente al país desde 1886 hasta 1930. El proyecto regenerador de Rafael Núñez inició mediante su decreto del 10 de septiembre de $1885^{7}$ por el cual se conformó el Consejo Delegado que se encargó de redactar la constitución de $1886 .{ }^{8}$ Núñez señalaba que la nueva Constitución era el reflejo de una Nación que deseaba reemplazar la anarquía por el orden, para él las Repúblicas debían ser autoritarias, porque de no serlo se conducirían a la autodestrucción. ${ }^{9}$ Dicha constitución tampoco logró evitar los enfrentamientos entre partidos, ni las guerras civiles, ni los golpes de estado, pero sentó las bases para el restablecimiento de las relaciones amistosas entre la Iglesia católica y el Estado colombiano, instituyendo, por ejemplo, al catolicismo como religión oficial de la Nación que debía desde ese momento en adelante ser defendida por los poderes gubernamentales. ${ }^{10}$

La situación de algunos espiritistas, debido a la Hegemonía Conservadora (1886-1930) y la instauración de la Constitución de 1886, cambió drásticamente. Algunos de los personajes que se mencionarán en este artículo sufrieron los afanes propios de las persecuciones y represiones debidas al cambio de gobierno y a sus inclinaciones políticas y espirituales.

El presente artículo no solo tiene por objeto mostrar los documentos hasta ahora encontrados (revistas, periódicos, libros, pasquines, artículos de prensa y folletines) para una historia del espiritismo en Colombia (1868-1889) ${ }^{11}$ que han sido preservados, en su mayoría por la Biblioteca Nacional de Colombia; sino que además pretende reconocer la relación entre el espiritismo e "ideas universales" 12 como las propias de la Revolución Francesa, la lucha por la libertad de cultos o la abolición definitiva de la esclavitud, todo esto siempre reconociendo el papel fundamental de

\footnotetext{
${ }^{7}$ El inicio de la Regeneración es un punto de discusión dentro de la historia en Colombia. Hay quienes afirman que este periodo empezó, con la Constitución de 1886 y la firma del Concordato con el Vaticano en 1887. También hay quienes opinan que la Regeneración empezó con la primera administración gubernamental de Rafael Núñez de 1880-1882, hay también quienes afirman que fue el final de la guerra civil de 1876-1877. David Cortés propone rastrear los inicios de la Regeneración desde finales de la década de 1860. Cortés, "Estado, iglesia y religión", 499.

${ }^{8}$ La Constitución de 1886 tuvo varios fundamentos: La centralización del poder público, la educación católica, el fomento del trabajo nacional, los ideales de fe, paz y progreso, el confesionalismo estatal: oficialización de la religión católica como la religión de la Nación, las limitaciones de las libertades públicas y el presidencialismo.

${ }^{9}$ Iván Darío Toro Jaramillo, El pensamiento de los católicos colombianos. En el debate ideológico de la “crisis de medio siglo" (1850-1900) (Medellín, Departamento de publicaciones fundación Universitaria Luis Amigó: 2005), 55.

${ }^{10}$ Toro, El pensamiento de los católicos colombianos, 63.

${ }^{11}$ Para ello, en un estudio previo se analizaron las fuentes primarias y secundarias para reconstruir las redes de impresión, de circulación y de recepción del espiritismo en ciudades de Colombia como Bogotá, Medellín y Sogamoso entre 1868-1889. Ana María Mancera, «Historia intelectual del espiritismo en Colombia». (1868-1889). Tesis de pregrado, Pontificia Universidad Javeriana, 2018.

${ }^{12}$ Quentin Skinner, Lenguaje política e historia (Buenos Aires: Universidad Nacional de Quilme, 2007), 109.
} 
las imprentas y el oficio del impresor, en las prácticas espiritistas. Para esto la idea de Quentin Skinner acerca de cómo se debe hacer una aproximación a este tipo de fuentes, es de suma importancia, ya que en los documentos espiritistas se reconocen conceptos fundamentales y cuestiones permanentes en el discurso de los Estados modernos, en esos documentos hay una valiosa reinterpretación sobre la moralidad, la política, la religión y la vida social. Lo asombroso del caso es que estas fuentes han sido escasamente analizadas, contextualizadas y se ha desconocido históricamente en Colombia cuál fue el aporte del espiritismo a la consolidación de nuestra cultura, de la política, la religiosidad, espiritualidad contemporánea.

En los documentos espiritistas a la vez que se divulgaban los avances científicos del momento; se debatía el asunto de la evolución (darwiniana) del alma; se explicaban las clasificaciones de médiums; se criticaba al catolicismo colombiano; se explicaban términos espiritistas; se opinaba sobre la importancia de la inserción de los espiritistas en la definitiva abolición de la esclavitud y se proponía al espiritismo como la religión adecuada para los tiempos y para los Estados modernos.

El estudio de la historia del espiritismo en Colombia permite hacer, como afirmó De Certeau, una "exhumación” de lo que implicó para algunas familias o personajes practicar el espiritismo y cómo en las ciudades de Bogotá y Medellín, algunos liberales radicales que gozaron de ciertas libertades intelectuales y posiciones socioeconómicas se refugiaron en este movimiento espiritual para criticar fuertemente al catolicismo colombiano y al conservadurismo político.

El espiritismo de la segunda mitad del siglo XIX y de las primeras décadas del siglo XX, hizo una interpretación magnífica de los valores de la Revolución Francesa y de la Ilustración, tales como la libertad, la igualdad y la fraternidad, valores que se convirtieron en los pilares intelectuales de los espiritistas, que en Colombia estuvieron estrechamente relacionados con círculos de intelectuales, masones, médicos, literatos, artistas, periodistas y políticos liberales radicales. ${ }^{13}$

En Colombia, mientras este movimiento consolidó un discurso que integró la ciencia, la espiritualidad, y el liberalismo radical en los círculos sociales fundamentales para la cultura nacional colombiana, fue considerado por el catolicismo como una "[...] secta diabólica que convertía a los hombres en brujos y nigrománticos, que los separaba de Dios y de la Iglesia Católica." ${ }^{14}$ Para nosotros es muy sencillo escapar de la vigilancia de instituciones como la Iglesia católica, pero en el siglo XIX en Colombia, el asunto era mucho más complejo. Escapar de las estructuras del catolicismo era muy difícil y quien no profesara el catolicismo estaba expuesto a una clase de exclusión

\footnotetext{
${ }^{13}$ Como José Benito Gaitán uno de los impresores más importantes de Bogotá en el siglo XIX (1827-1916) dueño de la imprenta de Gaitán, impresor de la primera edición de María de Jorge Isaacs, presidente de la Sociedad Espiritista Americana Sede Bogotá y editor de miles de textos http://catalogo.bibliotecanacional. gov.co/uhtbin/cgisirsi.exe/?ps=HpaVdfMLGG/B.NACIONAL/176760068/9

${ }^{14}$ BNC. Miscelánea José Asunción Silva, 15, pieza 5. Disponible en versión digital en http://catalogoenlinea. bibliotecanacional.gov.co/client/es_ES/search/asset/63043
} 
social que podía terminar en la ruina económica. Por ello las prácticas ${ }^{15}$ espiritistas como acto de resistencia a las instituciones de vigilancia conservadoras y católicas representaba un riesgo para la vida o para la estabilidad económica de una familia. La bancarrota, precisamente, fue el elemento de castigo resultado de la exclusión social del padre de María Cano, este fue el caso del espiritismo en el círculo de Medellín. Pero a pesar de la persecución las prácticas espiritistas, y siguiendo la tesis de De Certeau, estas lograron politizar un quehacer cotidiano que se relacionó, en este caso, con la libertad de culto y con la construcción de una cultura en la que se articuló el conflicto entre el espiritismo y la Iglesia católica.

\section{Imprenta de gaitán y espiritismo en Bogotá}

Actualmente en Bogotá, en bibliotecas como la Luis Ángel Arango y la Biblioteca Nacional de Colombia, se conservan las publicaciones espiritistas del siglo XIX. A continuación, se hace un acercamiento a la historia de la Imprenta de Gaitán, debido a que la mayoría de los textos espiritistas encontrados hasta el momento fueron publicados por esa imprenta, y se conoce por fuentes secundarias que su dueño, José Benito Gaitán era espiritista. Aunque la condición de producción de textos era difícil, las imprentas en Bogotá tuvieron un incremento después de 1848, año en el cual Tomás Cipriano de Mosquera estableció políticamente parámetros para establecer la imprenta de Echevarría Hermanos.

Sucesivamente se establecieron otras imprentas y muchas de ellas funcionaban con máquinas de vapor como la Imprenta de Gaitán, ${ }^{16}$ su dueño, José Benito Gaitán (1827-1916 ca.), desde joven trabajó como impresor, viajó en 1874 Europa como secretario de la Legación de Colombia en Francia, fue director del Partido Liberal en $1899^{17}$ y publicó periódicos de varios temas como El estudiante, que era una publicación sobre estudios y propaganda, La Nación, La Opinión, Diario de Cundinamarca ${ }^{18}$ y La Paz, que estaban dedicados a asuntos políticos, mientras que Phychis; La Nueva Idea; Parte moral del Evangelio; Doctrina Espiritista-Cristiana y El minero de la verdad; fueron publicaciones de carácter filosófico y espiritista.

En su investigación sobre la tipografía bogotana, Tarcisio Higuera afirmó que en 1880 ya existía la imprenta de José Benito Gaitán y que estaba ubicada entre las carreras octava y novena. Según Juan José Hoyos, este fue el primer edificio para imprenta que tuvo Bogotá y fue construido por el mismo José Benito Gaitán, Hoyos aseveró que la Imprenta de Gaitán se ubicaba en el edificio entre la esquina de la calle

\footnotetext{
${ }^{15}$ Michael De Certeau, «Introducción general», en La invención de lo cotidiano 1. Artes de hacer, (México D.F: Instituto Tecnológico y de Estudios Superiores de Occidente, A.C, 2000), XLIV.

${ }^{16}$ Tarcisio Higuera, “La imprenta en Colombia, 1737-1970”, (Bogotá: Instituto Nacional de Provisiones, 1970), 114.

${ }^{17}$ Joaquín Ospina, Diccionario Biográfico y bibliográfico de Colombia (Bogotá: Editorial Águila, 1937), 21.

${ }^{18}$ Según Higuera José Benito Gaitán fundó El Diario de Cundinamarca en 1866 y según Antonio Cacua, en 1869. Vale la pena llamar la atención sobre el hecho de que folletín Doctrina espiritista-cristiana fue impreso por la Imprenta del Diario de Cundinamarca.
} 
Las imprentas, el liberalismo radical y comunicación con espiritus: divulgación de las...

15 con carrera octava, ${ }^{19}$ allí se establecieron los talleres de impresión más completos de su época. ${ }^{20}$

Gaitán además escribió para el periódico literario, científico y noticioso El Album (sic) ${ }^{21}$ y asumió la publicación de la novela María ${ }^{22}$ de Jorge Isaacs ${ }^{23}$. Esta novela aparecía publicitada en los periódicos bogotanos y José Benito Gaitán anunciaba que estaba realizando en su imprenta una lujosa edición de ella. ${ }^{24}$ María que fue publicada en mayo de $1867^{25}$ cumplió en 2017 los 150 años de haber sido publicada y en Colombia se han hecho, desde ese año, conmemoraciones como la exposición de la Biblioteca Nacional de Colombia La María Digital ${ }^{26}$ en la que se muestra al público que Jorge Isaacs, autor de la novela, como José Benito Gaitán fueron liberales de ala radical.

El tipógrafo Abraham Gardeazábal ${ }^{27}$ en sus memorias de 1934 afirmó que la imprenta de Gaitán trajo a Bogotá la primera prensa Marinoni ${ }^{28}$ en 1876, y que esta imprenta estaba bien ensamblada y que tenía un edificio especial de dos pisos. ${ }^{29} \mathrm{La}$ Imprenta de Gaitán fue una de las empresas pioneras en ese oficio en Colombia, su dueño estuvo relacionado con una élite política, comercial e intelectual.

\footnotetext{
${ }^{19}$ Tal vez uno de los vestigios de la ubicación de la Imprenta de Gaitán, es que en ese lugar se ubican en Bogotá actualmente uno de los centros de compra y venta de libros nuevos y usados.

${ }^{20}$ Juan José Hoyos, "El tipógrafo más antiguo de Bogotá”, en La pasión de contar. El periodismo narrativo en Colombia 1638-2000, (Medellín: Editorial Universidad de Antioquia, Hombre Nuevo Editoras, 2009), 592-593.

${ }^{21}$ Antonio Cacua Prada, Historia del periodismo colombiano (Bogotá: Editorial Fondo Rotatorio Policía Nacional, 1968), 168.

${ }^{22}$ Portada de la primera edición de María de 1867 publicada por la Imprenta de Gaitán. Imagen tomada de Biblioteca Nacional de Colombia http://catalogoenlinea.bibliotecanacional.gov.co/client/es_ES/search/ asset/138300 (Consultado el 26 de junio de 2019).

${ }^{23}$ María Teresa Cristina, «María: Las vicisitudes de un texto», en Jorge Isaacs Obras Completas, ed. María Teresa Cristina (Bogotá: Universidad Externado de Colombia, Universidad del Valle, 2005), xxx.

${ }^{24}$ Esa primera edición fue revisada por Ricardo Carrasquilla, y la segunda edición (1869) fue revisada por Miguel Antonio Caro.

${ }^{25}$ Un año antes publicación de la misma Imprenta de Gaitán del folletín espiritista más antiguo encontrado hasta el momento.

${ }^{26}$ Véase Colecciones, Biblioteca digital en Biblioteca Nacional de Colombia, «La María Digital» http:// bibliotecanacional.gov.co/es-co/colecciones/biblioteca-digital/exposiciones/La\%20Maria/index.html (consultado el 22 de Julio de 2019).

${ }^{27}$ Quien llegó a Bogotá desde Medellín en 1880, trabajo en el Diario Oficial, en El Deber, periódico de José María Samper, y para La Imprenta de Gaitán.

${ }^{28}$ La prensa Marinoni, impresora o prensa rotativas es una máquina de impresión rotativa para la impresión de papel continuo. Al respecto ver: Rubén Gil, Periodismo: historia y teoría. Tomo 1. (Barcelona: Editorial CLIE, 1993), 58, https://books.google.com.co/books?id=pUmtJB3nRC4C\&pg=PA58\&lpg=PA58\&dq $=$ prensa+Marinoni\&source=bl\&ots $=$ HpL-cyudSY\&sig=gpcPj6XatvMMoiz3 GfpCwW0IHSc \&hl=es$419 \& \mathrm{sa}=$ X\&ved $=0$ ahUKEwjykojlmMHXAhWCC5AKHT3cBZ0Q6AEIOTAG\#v $=$ onepage $\& q=$ pren $\mathrm{sa} \% 20$ Marinoni\&f $=$ false.

${ }^{29}$ Higuera, "La imprenta en Colombia", 115.
} 
La primera publicación de la que hay registro de la Imprenta de Gaitán es El estudiante de $1866 .{ }^{30}$ Con la guerra de 1885 , muchas imprentas cerraron, pero, al parecer esto no afectó al punto de quiebre definitivo a la imprenta de Gaitán, puesto que en el catálogo de la Biblioteca Luis Ángel Arango la publicación de esa imprenta Pedro Rodríguez i la opinión pública fue editada en 1901. ${ }^{31}$ Las fechas de estas publicaciones nos permiten inferir que la Imprenta de Gaitán funcionó aproximadamente durante 35 años. Aunque también pudo ocurrir que por algunos años cesara su funcionamiento, pero al respecto no se encontraron datos que permitan afirmar esto con certeza.

Lo fundamental en la presente investigación es que José Benito Gaitán ${ }^{32}$ fue uno de los pioneros del oficio de la impresión en Bogotá y en el Papel Periódico Ilustrado, del 28 de octubre de 1882 aparece una mención a él:

El arte de la tipografía debe al señor D. Medardo Rivas, como a los hermanos Echeverría, a Gaitán y a Escobar la mayor parte del desarrollo del buen gusto a que han llegado y no es poco si comparamos las publicaciones del día con las que se hacían ahora hace 20 años. ${ }^{33}$

Por el tipo de trabajo de los impresores y tipógrafos no es de extrañar que Gaitán tuviera relaciones con personajes pertenecientes al mundo del gobierno. Debido a su oficio, Gaitán estableció vínculos con personajes como Mamerto García (1818-1881) importante comerciante antioqueño, que formó parte de los políticos liberales de la Convención de Rionegro, reunión en la que se estableció la Constitución de Rionegro, de 1863 carta magna por la cual se estableció el periodo denominado Olimpo Radical. A Mamerto García le escribió en repetidas ocasiones explicándole asuntos sobre el envío o la suscripción a "El Diario" como aparece en tres cartas preservadas (octubre 4 de 1871, noviembre 13 de 1872 y enero 21 de 1874) por la Biblioteca Nacional de Colombia.

La figura de José Benito Gaitán, un espiritista perteneciente a la élite intelectual y liberal puede ser analizada como la de un artesano de formación letrada ${ }^{34}$ que estuvo relacionado con la élite intelectual y política liberal de su época. El hecho de que su imprenta haya contado con las máquinas más sofisticadas de su época para realizar su trabajo, de que se relacionara con personajes como Jorge Isaac, que haya sido director del Partido Liberal y que haya viajado a Francia representando el

\footnotetext{
${ }^{30}$ Tomado del catálogo Opac de la Biblioteca Nacional de Colombia http://190.216.196.133/uhtbin/cgisirsi. exe/?ps=tK5vJqvjUf/B.NACIONAL/48230012/9 (Consultado el 17 de noviembre de 2017)

31 Tomado del catálogo de la Biblioteca Luis Ángel Arango. http://ticuna.banrep.gov.co:8080/cgi-bin/ abnetclwoi/O8036/IDa532b46c/NT2 (Consultado el 17 de noviembre de 2017).

${ }^{32} \mathrm{Si}$ era espiritista o no, no se han encontrado fuentes documentales que corroboren este hecho. Quien afirmó que Jose Benito Gaitán fue el presidente de la Sociedad Espiritista de Bogotá fue Gilberto Loaiza, en todos sus artículos sobre el tema ha afirmado lo mismo, pero no cita ninguna fuente.

${ }^{33}$ Papel Periódico Ilustrado, Número 29 del 28 de octubre de 1882. Citado por Higuera, "La imprenta en Colombia", 116.

${ }^{34}$ Gilberto Loaiza Cano, «Cultura popular y espiritismo (Colombia, siglo XIX)». Historia y espacio No. 32 (2009): 7.
} 
gobierno de Colombia, nos permite comprender que él era un hombre perteneciente a la élite, que contaba con medios económicos suficientes para adecuar de la mejor manera a su imprenta.

Las prácticas espiritistas en las que, posiblemente, estuvo involucrado Don José Benito Gaitán reunieron formas de lectura, debates, circulación de textos e industria editorial. Estas prácticas fueron también un conjunto de estrategias con las que se pretendió proponer y dar a conocer una espiritualidad anticatólica que involucró y que estuvo cercana al liberalismo radical, además de esto, el espiritismo colombiano del siglo XIX logró crear un lenguaje propio, cultural y científico que se evidencia en los textos espiritistas del siguiente apartado.

Gilberto Loaiza, en Manuel Ancizar y su época, analizando el papel de la imprenta en el establecimiento de las hegemonías en Colombia durante el siglo XIX, afirmó que los impresores eran respetados y que tenían un lugar de preeminencia dentro de la sociedad. Debido a que la imprenta era una empresa que, simbólicamente, permitía que el letrado se separara de los sectores populares y que les facilitaba la tarea de ilustrar y de civilizar, les brindaba a los impresores una cierta popularidad entre la sociedad, puesto que era sinónimo de mercado y de masificación en la reproducción de ideas. Loaiza afirma, «El impresor en su taller se convertía en el eje de las relaciones culturales y mercantiles de una sociedad $»^{35}$. Los impresores controlaban la publicación y la difusión de textos y dicho proceso de circulación estaba dominado por un grupo determinado de escritores y lectores que compartían los mismos espacios culturales y sociales. Es así como este círculo de producción, circulación y recepción se convertía en una red en la que se expresaban y se promovían intereses compartidos. ${ }^{36}$

Aunque el objetivo de este artículo es comprender el papel de este tipo de ilustrados o nuevos burgueses en la difusión de la doctrina espiritista en la escena colombiana del siglo XIX, vale la pena aclarar que si debieron haber existido una amplia gama de círculos, lecturas y prácticas relacionadas con la comunicación con los espíritus, que se alejaba de las mencionadas élites.

Quiero resaltar dos aspectos, el primero es que Loaiza, quien hizo uno de los pocos y valiosos estudios sobre el espiritismo en la historiografía colombiana, afirmó que el que se practicó en Colombia no solo fue un asunto de círculos eminentemente burgueses, muy por el contrario, el espiritismo para Loaiza fue una oportunidad de distanciamiento con las élites letradas y muy influenciadas por la cultura intelectual francesa. Y tal como Loaiza lo afirma el espiritismo se practicó en círculos muy diversos, entre quienes fueron receptivos a la comunicación con los espíritus hubo, abogados, médicos aldeanos, ${ }^{37}$ impresores, mujeres, y artesanos autodidactas. ${ }^{38}$

\footnotetext{
${ }_{35}$ Gilberto Loaiza, Manuel Ancizar y su época. Biografia de un político hispanoamericano del siglo XIX, (Medellín: Fondo Editorial Universidad Eafit, 2004), 14.

${ }^{36}$ Camargo, "Las rutas del impreso", 85

${ }^{37}$ Tal como el caso del doctor Joaquín Calvo Mendívil en Sogamoso, a él se hace referencia en el apartado de Distribución y divulgación de publicaciones espiritistas de este mismo artículo.

${ }^{38}$ Loaiza, "Cultura popular y espiritismo", 18.
} 
Y el segundo aspecto a resaltar es que, aunque el siguiente ejemplo sale de la fecha de investigación de este artículo hubo un caso de un artesano que se sentía atraído por la lectura prensa obrera bogotana y de libros de magnetismo, hipnotismo, espiritismo y sugestión: Leovigildo Galarza, quien acompañado de Jesús Carvajal asesinó en 1914 a Rafael Uribe Uribe. ${ }^{39}$ Así que en el espectro de comunicación con espíritus debió sin duda haber una gama amplia de personajes y sectores de la sociedad que no se reducían únicamente a las élites burguesas y liberales de Colombia en el siglo XIX.

\subsection{Producción de textos espiritistas 1868-1889}

Los espiritistas del siglo XIX en Colombia desarrollaron algunas maneras de hacer ${ }^{40}$ relaciones con el oficio de la impresión, en estas se usaron y se reprodujeron ideas anticlericales, anticatólicas, liberales y románticas que tuvieron la intensión de liberar al hombre del siglo XIX de la tergiversación de la fe que, según ellos, había establecido el catolicismo, en Parte Moral del Evanjelio esplicado por los espíritus perfectos, hay un apartado llamado Comunicación de un espíritu que se firmó Manuel José Mosquera, Arzobispo de Bogotá:

Pero ¿quién fue la causa de esa muerte del jérmen que Dios habia sembrado en el evangelio por medio de Jesus? ¿Quién?

Penoso es confesarlo: los mismo que se atribuyeron la mision de dirijir la conciencia de la humanidad. Ellos i no otros estraviaron y estravian todavía del sendero trazado por Jesus.

La mayor parte de los papas, de los obispos, de los clérigos i de los concilios romanos, i griegos, propusieron el bien de la humanidad, una jeringonza que llamaron ciencias sagradas; i ahogaron la humanidad en el piélago de las formas, pisoteando con descaro el fondo religioso imoral del cristianismo. [...] El romanismo cometío la torpeza de prohibirle al hombre el razonar, pues la razon humana ha estado siempre en pugna contra los dogmas inintelijibles de la iglesia romanista[...] Toda secta, toda relijion, toda doctrina social, moral o científica, que le exija al hombre que no haga uso diario i continuo de su razon, es atea, i el ateísmo, lo mismo que el materialismo, destruye en el hombre que lo profesa, su elemento moral, único que puede hacerle andar infaliblemente por el camino de su gravitación natural hacia Dios. (sic) ${ }^{41}$

Parte Moral del Evanjelio esplicado por los espiritus perfectos es un folleto ${ }^{42}$ espiritista publicado en 1868 por la Imprenta de Gaitán, en este documento, aparte de la comunicación citada anteriormente, también hay un pequeño vocabulario espiritista en el que se definen términos como alma, caridad, castigos, espíritu, equidad, fe,

\footnotetext{
${ }^{39}$ Alberto Mayor Moya, "24 horas en la vida de dos artesanos de 1914”, Revista colombiana de sociologíaNueva Serie 2, no. 2 (1993-1994): 48.

${ }^{40}$ De Certeau, «La invención de lo cotidiano», 78.

${ }^{41}$ Biblioteca Nacional de Colombia, Miscelánea José Asunción Silva, 424, Pieza 12. Disponible en formato http://catalogoenlinea.bibliotecanacional.gov.co/client/es_ES/search/asset/75043 (29/07/12019)

${ }^{42}$ La designación de folleto, libro y monografía ha sido escrita en esta investigación utilizando la información brindada por el señor Germán Rivera, bibliotecario de la B. N. C, entrevistado por la autora, Bogotá, 28 de diciembre de 2017.
} 
Ilustración, matrimonio etc. Se resalta la afirmación espiritista de que el catolicismo romanizado se había convertido en la institución que engañaba a los hombres, haya sido dada por el espíritu del arzobispo Manuel José Mosquera, quien fue hermano de dos presidentes de Colombia Joaquín y Tomás Cipriano de Mosquera, ${ }^{43}$ el arzobispo, en vida, había sido rechazado por los artesanos y por algunas Sociedades Democráticas que querían desterrar a los jesuitas del país en la década de $1850 .{ }^{44}$

De 1870 a 1871 hubo doce números de la revista Psychis o Estudios del Alma Humana, que fue publicada en Bogotá también por la Imprenta de Gaitán. En esta revista los temas son de carácter científico, moral, y también sobre la naturaleza de Dios. Los autores originales de la mayoría de los artículos fueron los espiritistas franceses Allan Kardec (1804-1869) y Camille Flammarion (1842-1925), quien, a su vez, era astrónomo. Uno de los artículos de Flammarion fue Los tiempos han llegado, este fue traducido de la Revue Spirite de París de diciembre de 1869 y fue publicado en el número 2 de la revista Psychis, en el artículo se afirma que la finalidad de la humanidad es la ley del progreso, para Flammarion la tierra había cambiado para que en ella habitaran seres cada vez más evolucionados física y moralmente. La humanidad progresaba, según él, por medio de la inteligencia, por el sentido de desarrollo moral y al mismo tiempo que se adquiría más conocimiento científico, se depuraba de la tierra a la vez religiones "insalubres". ${ }^{45}$

Flammarion proponía que, con el espiritismo, la fraternidad, sinónimo de la caridad predicada por Cristo, renacería un sentimiento de reciprocidad de los deberes sociales, de hombre a hombre, de pueblo a pueblo y de raza a raza. Es decir, la esencia del nuevo orden social que debía surgir frente a los cambios de finales del siglo XIX era la fraternidad basada en la fe. El espiritismo para Flammarion abogaba por la reconciliación de las religiones en el hecho de reconocer que Dios es el mismo para todos ${ }^{46}$ Es decir, al contrario de las religiones tradicionales, el espiritismo no afirmaba que fuera de este no había salvación, de hecho, reconocía que todos los seres podían ser salvados, pero por medio de la caridad, sin importar la religión que se profesara, así que la piedra angular del espiritismo era principalmente la caridad. ${ }^{47}$ Aunque quedará claro más adelante que el cristianismo, según los espiritistas, había tergiversado el mensaje del evangelio.

\footnotetext{
${ }^{43}$ Ana María Mancera, "150 años de la publicación de un texto espiritista en Bogotá: Parte Moral del evangelio, explicado por los espíritus perfectos" Pieza del mes. Biblioteca Nacional de Colombia, (29/07/2019) DOI: http://bibliotecanacional.gov.co/es-co/actividades/Publicaciones-sobre-el-patrimonio/ Pieza-del-mes/detalle-pieza-del-mes?titulo=150\%20años $\% 20 \mathrm{de} \% 201 \mathrm{a} \% 20$ publicación $\% 20 \mathrm{de} \% 20$ un $\% 20$ texto $\% 20$ espiritista $\% 20$ en $\% 20$ Bogotá:\%20Parte $\% 20$ moral $\% 20$ del $\% 20$ evanjelio, $\% 20$ explicado $\% 20$ por $\% 2010$ \% $\% 20$ esp $\%$ C3\%ADritus $\% 20$ perfectos.

${ }^{44}$ Nancy Otero Buitrago, Tomás Cipriano de Mosquera. Análisis de su correspondencia como fuente historiográfica y mecanismo de poder. 1845-1878 (Cali: Universidad del Valle, 2015), 99.

${ }^{45}$ Camille Flammarion, «Los tiempos han llegado», Psychis o estudios del alma humana, no. 2 (1871): 21.

${ }^{46}$ Camille Flammarion 25.

${ }^{47}$ Camille Flammarion 30.
} 
El periódico La nueva Idea fue publicado en 1873, por la imprenta de Gaitán y fue definido por su autor como un periódico, el contenido principal de este periódico fue el de publicar en español los lineamientos espiritistas de Allan Kardec; a diferencia de otras fuentes primarias en que solo se resumen y se explican los fundamentos del espiritismo, en La Nueva Idea, hay escritos de un espiritista que ataca con exaltación al catolicismo. En esta publicación quincenal, su redactor afirma que el catolicismo no es en ningún sentido la institución que pueda combatir al materialismo, ya que la misma Iglesia católica es materialista:

[..] para nosotros hai una distinción cardinal entre el cristianismo-sublime e inefable doctrina predicada por el filósofo de la Judea-i el catolicismo o romanismo - conjunto grosero de prácticas pueriles i supersticiosas, misticismo enervador de espíritu i rémora de la Humanidad, que ha venido adulterando de tal manera la pureza de las enseñanzas de Cristo, que hoy puede haber cuanto se quiera en el catolicismo menos relijion cristiana(sic)»

Este discurso de crítica al catolicismo es bastante fuerte y no es como las otras publicaciones en las que se hace una descripción más pacífica de lo que el catolicismo significaba para el espiritismo; en este texto se ataca, se critica de una manera frontal, directa y beligerante a la Iglesia católica, todo esto en función de presentar al espiritismo como la propuesta que traerá al mundo la luz de una fe adecuada a su época. Al respecto, es fascinante encontrar que Víctor Hugo, otro espiritista, en la segunda parte, libro séptimo de Los Miserables, publicada en 1862 escribió algo similar a las ideas de las fuentes primarias que se mencionan:

No nos limitemos a prosternarnos ante el árbol de la Creación y a contemplar sus inmensas ramas cuajadas de estrellas. Tenemos un deber más alto: trabajar en pro del alma humana, defender el verdadero misterio contra el falso milagro, adorar lo incomprensible y rechazar lo absurdo, no admitir en cosas inexplicables más que lo necesario, purificar la creencia, barrer las supersticiones sobre la religión, limpiar de gusanos la idea de Dios. ${ }^{48}$

Como lo evidencia la cita anterior de Víctor Hugo y las fuentes documentales para este estudio el espiritismo que influenció y que llegó al contexto colombiano fue el francés. ${ }^{49}$ Parte del discurso espiritista colombiano del siglo XIX se construyó con base en la crítica hacia el proceso de romanización de la Iglesia católica. Así se ha podido ver tanto en la comunicación con el espíritu del arzobispo Manuel Mosquera, como en el artículo ¿Por qué el catolicismo diviniza la materia? del periódico $L a$ nueva idea, en el que se afirma:

\footnotetext{
${ }^{48}$ Víctor Hugo, "Paréntesis", Los Miserables, Parte Segunda, Libro séptimo. Traducido por Nemesio Fernández- Cuesta (España: Biblok Book Export, S.L, 2017) 445.

${ }^{49}$ Además, en los documentos espiritistas no se encontraron referencias o traducciones de espiritistas ingleses como Sir Arthur Conan Doyle que también publicó novelas y textos teóricos sobre el espiritismo. Al respecto véase de Sir Arthur Conan Doyle, El país de la bruma. Novela espiritista. (Madrid: Ediciones Oriente, 1929)
} 
Las imprentas, el liberalismo radical y comunicación con espiritus: divulgación de las...

Por eso nosotros, no solo no escusamos, sino que venimos a provocar el combate contra esos errores, encarándonos con el romanismo, ya que es la creencia relijiosa del pais en que vivimos; del mismo modo que lo hiciéramos con el islamismo, si morásemos en Asia: cada cual es obrero del taller universal, cumpliendo su parte de labor en el lugar que le toque suerte. (Sic) $)^{50}$

Hay otras características del catolicismo atacadas por los textos espiritistas, por ejemplo, se juzga la ostentación de la Iglesia católica, la idolatría de las representaciones materiales de los Santos, la fe que deposita el católico en una estatua, figura o efigie. Para los espiritistas esto no es más que una distracción para quienes son pobres e ignorantes de espíritu. Una de las ideas que quieren resaltarse de La Nueva Idea es el reproche que se hace al prestigio desmedido que tienen los representantes de la Iglesia católica:

Observad a un prelado en plena función religiosa: ahí está como un rei en su trono recibiendo homenajes i adoraciones a la par de la otra Majestad divina, que preside el acto; los hombres se le arrodillan i de rodillas le sirven; una bendicion suya es bendicion de Dios; un anatema de sus labios es maldicion divina; se le besa la mano o se le lamen los pies, según la jerarquía... I tanta pompa, i tanto boato, i servilismo tanto ¿es por ventura relijion? (sic). ${ }^{51}$

El espiritismo en Colombia no atacó al evangelio, sino que recalcó lo que para ellos eran los peores males del catolicismo, el discurso espiritista hizo una fuerte crítica a la posición económica, social y política de la Iglesia. Gaitán dio varios argumentos en contra del catolicismo de Colombia, por ejemplo, afirmaba que los sacramentos representaban una fuente inagotable de riquezas para la Iglesia y que la confesión, era una de las perversiones con las que la Iglesia lograba controlar las conciencias de los católicos, por eso su crítica iba dirigida hacia los creyentes que no filtraban por medio del uso de la razón los dogmas que les eran enseñados:

¿Qué es un católico? Helo aquí: Es un ser pasivo que cree i confiesa lo que la Curia Romana le ordena que crea i confiese. Todo católico hace, pues, abdicación, en favor de su Santa Madre Iglesia, de la mas precisa facultad: la razón. El católico, a fuer de su sometimiento a la Curia Romana, cree en la infalibilidad del Papa; en la eternidad de las penas; en el poder de la confesión, por la cual se borran todos los pecados; en la resurrección de la carne, i en todos los dogmas del Catolicismo. En cuanto a la parte práctica, los católicos son, en lo general, intolerantes, vengativos i perseguidores $i$ en el nombre de

Dios queman herejes. $(\mathrm{Sic})^{52}$

Hay que tener en cuenta que el espiritismo no pretendía que la gente dejara sus religiones, ya que se podía se espiritista y católico, o musulmán o judío etc. y ser a la vez espiritista, lo que pretendía este discurso era hacer que los individuos ejercieran su espiritualidad de una forma más racional, que no creyeran ciegamente

\footnotetext{
${ }^{50}$ Gaitán, “¿Por qué el catolicismo diviniza la materia?”, 18.

${ }^{51}$ Gaitán, “¿Por qué el catolicismo diviniza la materia?”, 19.

${ }^{52}$ Gaitán 19.
} 
en los mandatos de las religiones tradicionales y que rechazan cualquier expresión de fe que demandara una nulidad del ejercicio de la razón.

El folleto titulado El minero de la verdad. El espiritismo en su mas simple espresion; escrito en frances por M. Allan Kardec (sic) fue publicado en 1874 por la Imprenta de Gaitán, en éste hay un resumen de un libro titulado del mismo modo en el que Kardec explica el espiritismo. En el folleto "el espiritismo no es una relijión especial; es independiente de toda forma de culto; no prescribe ninguno, ni se ocupa de dogmas particulares; no tiene sacerdotes ni templo"53 en ese documento también hay un resumen de la enseñanza de los espíritus, en las que hay afirmaciones como "1. Dios es la inteligencia suprema, causa primera de todas las cosas. Dios es eterno, único, inmaterial, inmutable, omnipotente soberanamente justo i bueno. Es infinito en todas sus perfecciones" 54 .

En 1884 la imprenta del Diario de Cundinamarca ${ }^{55}$ publicó en Bogotá la tercera edición de Doctrina Espiritista-Cristiana o mi profesión de fe moral i relijiosa (sic), el folleto es una traducción de un texto no referenciado, firmado al final con el pseudónimo de Pelealethes, este documento consta de trece capítulos en los que se explica, desde una perspectiva espiritista, la historia de las religiones, el amor como ley universal, la vida espiritual, la creación, entre otros apartados. Hay dos ideas fundamentales que vale la pena resaltar, la primera es que se explica que para el espiritismo Jesús no era una figura divina, sino que fue el más grande de los espíritus encarnados:

La renovación relijiosa de un pueblo es obra de los espíritus superiores encargados especialmente por Dios de esa misión santa: Cristna, Buda, Confucio, Zoroastro, Moises, Mahoma, Manco-Capac, etc., que los pueblos han divinizado por admiración i gratitud. El más grande i perfecto de los espíritus encarnados al efecto ha sido Jesus de Nazareth, llamado por escelencia el Cristo o enviado de Dios (sic) $)^{56}$

La segunda idea importante por resaltar aparece en el capítulo IX del mismo documento, allí se explica el amor como ley moral, como esencia de Dios, y se afirma que "Las mujeres son espíritus superiores a los hombres, porque tienen la misión en la tierra de enseñar amando" "57. Una idea bastante problemática por elevar a la mujer como un ser espiritualmente superior del hombre, como cuerpos encarnados

\footnotetext{
53 "El minero de la verdad. Entrega I. El espiritismo en su más simple espresion por M. Allan Kardec" (sic) Biblioteca Luis Ángel Arango, Colección de documentos en la Biblioteca Virtual de la Biblioteca Luis Ángel Arango Miscelánea 683. Disponible en formato digital en http://www.banrepcultural.org/sites/ default/files/brblaa304638.pdf

54 "El minero de la verdad" 18.

${ }^{55}$ Que era impreso en la Imprenta de Gaitán.

56 "Doctrina Espiritista-cristiana o mi profesion de fe moral y relijiosa" (sic) Biblioteca Luis Ángel Arango, Miscelánea 1193, colección Eduardo Nieto Calderón. Disponible en formato digital en http://babel. banrepcultural.org/cdm/singleitem/collection/p17054coll10/id/866

57 "Doctrina Espiritista-cristiana o mi profesión de fe moral y relijiosa", 22.
} 
Las imprentas, el liberalismo radical y comunicación con espíritus: divulgación de las...

por espíritus más evolucionados. En el citado Parentesis de Los Miserables Victor Hugo afirmó:

Somos partidarios de la religión en contra de las religiones.[...] El monasterio, considerado en sí mismo e idealmente, y mirando bajo todos sus aspectos para hacer un examen imparcial, el convento de monjas sobre todo - porque en nuestra sociedad la mujer padece más, y hace una especie de protesta en el destierro del claustro-, el convento de monjas, decimos [...] es el estrecho y brumoso límite que separa dos mundos, iluminado y oscurecido por los dos a la vez; el punto en que se confunden el rayo debilitado de la vida y el rayo sombrío de la muerte; es la penumbra de la tumba. ${ }^{58}$

El 10 de marzo de 1889, la Imprenta de El Espectador en Medellín publicó A los espiritistas, en este documento el Centro Espírita de esa ciudad presentó las conclusiones del primer congreso espiritista resumidas por el llamado Visconde de Torres- Solanot, un español practicante del espiritismo. El artículo comienza:

Así en el mundo de las ideas, como en el mundo físico, las tinieblas se hacen más densas pocos momentos antes de aparecer la Luz[...] Seguid, y para que podáis vigorizar vuestras creencias, para que conozcáis el desarrollo que en el planeta, salido ya de la menor edad, va alcanzando la ciencia experimental que á la vez que ciencia es sistema y religión, el Espiritismo, os damos hoy, tomado íntegramente de un periódico extranjero, lo que leeréis á continuación y que para todos es consuelo y esperanza (Sic).$^{59}$

En este texto se describe cómo fue el Primer Congreso Internacional en Barcelona, según su autor, los delegados del Centro Espiritista Español se reunieron para reconocer a sus invitados, para establecer el número de centros espiritistas y los grupos que representaban algunas naciones, los países que se hicieron presentes fueron: Bélgica, Chile, Brasil, Francia, Holanda, Italia, Argel, España, Portugal, Isla de Cuba, México, Alemania, Rusia, Turquía, Perú, Colombia, Provincias Argentinas, Islas Baleares y Corfú. En el primer Congreso Espiritista Internacional se acordó la existencia del espiritismo como ciencia integral y progresiva, de la cual sus fundamentos eran la existencia de Dios, la infinidad de mundos habitados, la demostración experimental de la supervivencia del alma humana por la comunicación medianímica con los espíritus, la infinidad de las fases de la vida permanente, el hecho de que hay penas como consecuencias naturales de los actos, el progreso, la comunión universal y la solidaridad.

El carácter del Espiritismo en ese entonces fue manifestado como una forma de una ciencia positiva y experimental, como una forma contemporánea de revelación, como consagración de una etapa importantísima en el progreso de la humanidad, la solución a los más profundos problemas morales y sociales, de hecho dos de los objetivos que se declararon en ese congreso eran, en primer lugar, contribuir a que la

\footnotetext{
${ }^{58}$ Víctor Hugo 449.

${ }^{59}$ El vizconde de Torres-Solanot. "A los espiritistas" Imprenta de El espectador. Medellín, 1899, 1. En BNC, Miscelánea J.A.S 713.
} 
educación fuera de carácter universal y, en segundo lugar, a luchar por medio del uso de los espiritistas del oficio de la impresión a la definitiva abolición de la esclavitud. ${ }^{60}$

Una forma con la que también se puede analizar la historia del espiritismo en Colombia es que, mediante la evidencia de este tipo de publicaciones, se pueden establecer los vínculos que los impresores y el espiritismo, de esta forma queda claro que este tema se encuentra irremediablemente asociado con la historia de los medios de comunicación no solo en nuestro país, sino en los países en los que hubo presencia de sociedades espiritistas. En impresores como José Benito Gaitán y Fidel Cano (de quién se encontrará información en el apartado sobre el espiritismo en Medellín) son visibles las formas en las que comenzaron, en el siglo XIX, a sustituirse las tradiciones en la comunicación anteriores a 1848, estas publicaciones espiritistas son un ejemplo de cómo hubo una pretensión de que los textos llegaran a una mayor cantidad de lectores, eso sí, sin desconocer en ningún momento que las altas tasas de analfabetismo eran enormes en la sociedad la colombiana de la segunda mitad del siglo XIX en Colombia.

La publicación de estos textos espiritistas hace parte de una producción cultural que se fabricaba por medio de la tecnología, la racionalidad y las técnicas de impresión con industrializada, con el objetivo de llegarle a una clase social que pudiera, por medio del estudio del espiritismo, separarse de la clase social tradicional y católica.

Lastimosamente no se encontraron rastros que hayan conducido a dilucidar quién era el mediador, quién se encargaba de traducir, resumir, adaptar y editar los textos de tradición espiritista que provenían de Europa. Pero se puede afirmar, sin confirmarlo por medio de fuentes primarias, que era José Benito Gaitán quien hacía todas esas labores en el círculo de producción del espiritismo, pero en esta labor pudieron haber estado involucradas muchas personas de las que no se encontraron evidencias. Aunque no se ha podido determinar en dónde, ni quiénes vendían los textos espiritistas impresos en Bogotá, se pudo confirmar, como lo afirma Gilberto Loaiza y como se puede reconocer en los mismos documentos espiritistas, que fue la versión francesa del espiritismo la que llegó a nuestro país con textos de Allan $\operatorname{Kardec}^{61}$ y de Camille Flammarion traducidos y adaptados al público colombiano.

\footnotetext{
60 “A los espiritistas” Medellín 1899. Biblioteca Nacional de Colombia, Miscelánea José Asunción Silva 713.

${ }^{61}$ Los orígenes carismáticos de ciertos liderazgos espiritistas se ejemplifican claramente en los casos del sistematizador del espiritismo europeo, el pedagogo Léon-Hippolyte Rivail, más conocido como Allan Kardec (Lyon, 1804- París, 1869), sustituido a su muerte por Léon Denis (Foug, 1846-1927) y por la de la divulgadora mundial más importante del espiritismo en lengua castellana durante el XIX, Amalia Domingo Soler (Sevilla, 1835-Barcelona, 1909). Gerard Horta, «Espiritismo y carisma. Orígenes carismáticos del liderazgo en el movimiento espiritista europeo del siglo XIX», Gazeta de antropología 20, No. 10. (2004), 2.
} 


\subsection{Distribución y divulgación de publicaciones espiritistas}

Frente al asunto de la comercialización de obras espiritistas, hubo un hallazgo que permite especular en dónde se vendían este tipo de obras en Bogotá. El libro ¿Qué es el espiritismo? Introducción al conocimiento del mundo invisible por las manifestaciones de los espíritus ${ }^{62}$ escrito por Allan Kardec, ${ }^{63}$ fue vendido en Bogotá por la Librería Barcelonesa de Soldevilla y Curriols, que inició operaciones en 1873.

Después de 1886 y del restablecimiento de algunas relaciones con España, en el marco del establecimiento de la Constitución conservadora, hubo algunas renovaciones en el mercado cultural; en el caso de Bogotá, una de las librerías que se benefició de esos cambios fue la Barcelonesa. Al contrario de lo que se vendía en la librería de Miguel Antonio Caro, que eran obras para la clase alta, destinadas a reforzar el asunto del buen uso del castellano y de la ortodoxia católica, en la librería Barcelonesa, hubo un mercado de libros que permitió el inicio de una clase de masificación en la lectura de textos, según Laureano García Ortiz:

«[...] se abría el apetito de las pobres imaginaciones con toda clase de misterios: Los misterios de la inquisición, los misterios del Escorial, los misterios del lecho conyugal [...] el catalán Curriols ${ }^{64}$, sin criterio científico, ni moral, ni artístico [...] satisfacía los gustos pervertidos de los muchachos, con las más apestosas pornografías. Así convertía la noble función social de fomentador e intermediario de las relaciones espirituales entre los hombres, en oficio rufianesco» ${ }^{65}$

Laureano García no mostraba otra cosa que desprecio hacia la librería Barcelonesa, pero fue esta, la más exitosa de Bogotá en las décadas de 1910 y 1920. En ella hubo rasgos, según Rubén Darío Flórez, de la masificación del mercado de textos que coincidió con el surgimiento de una cultura popular letrada y urbana en Bogotá, esta librería es un ejemplo de cómo se consolidó una actitud urbana y moderna hacia el libro que permitió que se generalizara su intercambio, la Barcelonesa tenía en cuenta los intereses de los lectores bogotanos, ofrecía traducciones para lectores de mediana formación intelectual ${ }^{66}$ que no dominaran por completo idiomas como el francés o el latín, por esa razón no es de extrañar que algunas obras de Allan Kardec, traducidas al español se encontraran en dicha librería.

\footnotetext{
${ }^{62}$ Allan Kardec, ¿Qué es el espiritismo? Introducción al conocimiento del mundo invisible por las manifestaciones de los espiritus. Traducida por la Sociedad Barcelonesa propagadora del espiritismo. Barcelona: Sociedad Barcelonesa propagadora del espiritismo.

${ }^{63}$ Este libro fue escrito en 1859 y una de las traducciones que se hicieron en el siglo XIX fue la de la Sociedad Barcelonesa Propagadora del Espiritismo en 1871.

${ }^{64}$ Rubén Darío Flórez, "Lectores de bibliotecas vs una biblioteca de lector", Entornos, 30, No. 1. (2017): $67-78$.

${ }^{65}$ Laureano García Ortiz, Las viejas librerías de Bogotá. Discursos académicos. Biblioteca de la Presidencia de la República, 2. Presidencia de la República, Bogotá. 21-39. http://www.bdigital.unal.edu.co/397/ (Consultado el 24 de 4 mayo de 2019)

${ }^{66}$ Flórez, "Lectores de bibliotecas vs una biblioteca de lector", 74.
} 
En Bogotá, el hecho de que el espiritismo se ligara con quien hacía traducciones de textos espiritistas para luego publicarlas en forma de periódicos, revistas y folletos y que se vendieran textos de Allan Kardec con el objetivo de masificar las ideas espiritistas, hace referencia a un ejemplo del inicio de una transición en la concepción de masas que es afín a la creación de espacios en los que se criticara el viejo orden de la sociedad y de la religión. Poner textos al alcance de cualquiera que pudiera comprarlos, muestra que había una pretensión de que el movimiento espiritista se convirtiera en algo medianamente masivo; esto con el objetivo de que una comunidad espiritista global pudiera tener el poder de transformar tanto a la religión como a la sociedad. Por lo anterior los en las publicaciones espiritistas se firmaba que los mensajes que los espíritus les revelaban le traerían felicidad al mundo entero, pero ese proyecto no puede en ningún momento desligarse del poder que tenían los impresores como agentes de transformación social.

Acerca de esta transición, Martín Barbero afirmó que estos cambios se relacionan con el descubrimiento político de la multitud como un actor político ${ }^{67}$. En este caso que se masificara el espiritismo por medio de las imprentas y por medio de la venta de libros de Allan Kardec en Bogotá, se relaciona con el hecho de que el espiritismo, consumido como un asunto que podría haber sido masivo, hubiera tenido el poder de erosionar la cultura y desintegrar el viejo orden. Ese específicamente fue el objetivo del espiritismo en Colombia en el siglo XIX: volver este movimiento una comunidad con el poder de masificar sus críticas a la moral y a la religión católica, para que la sociedad misma fuera la que se convirtiera felizmente al espiritismo y rechazara las religiones caducas - como los mismos espiritistas definían al catolicismo-. Fue un proyecto que, influenciado por su contexto, por los debates políticos, por el Romanticismo, por la filosofía, por la teosofía y por el liberalismo, llegó a Colombia para luchar contra cualquier institución que planteara que la razón no podía en ningún sentido meterse en asuntos de fe.

Si bien no se han podido encontrar fuentes con las que se pueda determinar qué clase de lectura ${ }^{68}$ se hacía de las publicaciones espiritistas, hubo un caso en Sogamoso, un municipio del departamento de Boyacá, durante el periodo del Olimpo Radical, que permite evidenciar en concreto la persecución de la Iglesia católica hacia quienes practicaban el espiritismo y quienes leyeron el folleto Parte Moral de Evangelio. El planteamiento de la Iglesia católica hacia los "adversarios del catolicismo", es decir, los liberales, positivistas, masones y protestante, ${ }^{69} \mathrm{era}$ que debían combatirse. A continuación, se narrará brevemente, parte de un extenso caso que permite reconocer en un pequeño de grupo de espiritistas, y en un personaje

\footnotetext{
${ }^{67}$ Jesús Martín Barbero, "Ni pueblo ni clases", en De los medios a las mediaciones. (México D.F: Editorial Gustavo Gili, S.A: 1987), 32-35.

${ }^{68}$ Martín Barbero explicó en De los medios a las mediaciones que había dos tipos de lectura: la lectura oral o auditiva, que era la que se realizaba en voz alta y colectivamente, debido a que no todos los participantes de estos espacios de transmisión de ideas sabían leer; y la lectura silenciosa del letrado, que era la que se hacía individualmente. Jesús Martín Barbero, "Ni pueblo ni clases", en De los medios a las mediaciones. (México D.F: Editorial Gustavo Gili, S.A: 1987), 32-35

${ }^{69}$ Rodolfo de Roux,
} 
Las imprentas, el liberalismo radical y comunicación con espiritus: divulgación de las...

en específico las implicaciones reales de realizar sesiones espiritistas y de rechazar algunos de los dogmas del catolicismo.

El folleto Parte Moral del Evanjelio, fue llevado a Sogamoso, un municipio en el actual departamento de Boyacá en Colombia, por Joaquín Calvo Mendíbil, un médico que estudió en Francia, y llegó a ese municipio a fundar, según el presbítero José Nepomuceno Rueda, una escuela espiritista. ${ }^{70}$ Ante esto el sacerdote, defendiendo los dogmas de su iglesia atacó ferozmente al médico. En los documentos de esta historia que fue relatada principalmente por Rueda, él afirmó:

«El espiritismo de hoy es el mismo pythonismo de la antigüedad: la voz griega Python significa adivino, májico i nigromántico: la palabra hebrea que le corresponde i que le asignaron los hebraizantes, es $o b$, en el plural oboth i señala por ella no solo un adivino, un hechicero, un espíritu familiar; sino también el arte de adivinar cosas ocultas, de predecir lo venidero i de evocar las almas d ellos muertos.» (sic) $)^{71}$

Ante la amenaza que para Rueda significaba el espiritismo, se debía actuar de manera radical, en Conferencia sobre el espiritismo, publicación de la Imprenta de Ortiz Malo, se reúnen varios documentos fechados desde marzo hasta abril de 1869. En ellos Rueda narra que a la llegada del Dr. Calvo a Sogamoso hubo la necesidad de hacer esa conferencia porque según él, los enemigos del catolicismo,

«[...] á falta de razones, han hecho uso de invectivas poco honrosas para sostener los principios protestantes y han procurado hacer pulular la noticia de que yo no pude resistirle al doctor Calvo esta discusión, que me batió, que me despedazo, y ha habido personas de las que no asistieron que digan que el doctor Calvo hablo en siete idiomas y yo no pude contestarle en ninguno». $(\mathrm{Sic})^{72}$

Más allá de los detalles de todo el asunto, ${ }^{73}$ la respuesta de Rueda hacia las prácticas del Dr. Calvo se explican debido a las actuaciones propias de la Iglesia católica que en 1864 bajo la proclamación del Syllabus ${ }^{74}$ del papa Pío IX, había condenado los errores de mundo moderno: el panteísmo, el racionalismo y el liberalismo. Sin caer en el debate sobre la intransigencia de la Iglesia católica ante el progreso del mundo moderno, es importante reconocer en el contexto de ese momento una crisis ${ }^{75}$, debida en parte a los cuestionamientos sobre la salvación que, por múltiples ideas, le había quitado al catolicismo el monopolio de la fe, el papel del papa, la salvación, la relación entre la Iglesia y los estados modernos y la tolerancia religiosa.

\footnotetext{
${ }^{70}$ BNC, Miscelánea José Asunción Silva, pieza 846, f. 2.

${ }^{71}$ BNC, Miscelánea J.A.S, pieza 846, f. 4.

${ }^{72}$ BNC, Miscelánea José Asunción Silva, 718, pieza 15, f. 3.

${ }^{73}$ Detalles que se narran en un artículo entregado a la revista Diseminaciones de la Universidad Autónoma de Querétaro que se encuentra en proceso de evaluación.

${ }^{74}$ Syllabus errorum. Catálogo que comprende los principales errores de nuestra época señalados en las encíclicas y otras cartas apostólicas de nuestro santísimo Señor Pío Papa IX.

${ }^{75}$ Elisa Cárdenas Ayala, «El fin de una era: Pío IX y el Syllabus», en Historia Mexicana, El colegio de México 65, no. 2 (2015):739.
} 
Si bien el doctor Calvo, en uno de los documentos del caso que presentó Rueda, se declaró católico, apostólico y romano el 12 de marzo de $1869,{ }^{76}$ su historia parece haber terminado mal. En un pasquín publicado en Sogamoso el 19 de abril de 1869, titulado Una explicación al público, un pequeño grupo de espiritistas que apoyaban al Dr. Calvo relataron:

Si nuestro dicho nada vale porque, segun el presbítero Rueda. No somos católicos-romanos o porque estamos escomulgados [...] Nosotros que nos honramos con el título de discípulos del doctor Calvo i a quien tenemos un respeto i agradecimiento profundos, no tenemos porque estrañar que se nos calumnie como a él; como no estrañamos que el presbítero Rueda, según sus precedentes, nos haya calumniado con el laudable objeto de engañar al público desmintiendo la verdad. [...] Por lo que respecta al hecho de habernos escondido en los momentos de peligro, apelamos al testimonio de los mendigos i demas notables, a quienes él mismo (Rueda) logró engañar para asaltar la mui respetable casa de los señores Izquierdo i asesinar al doctor Calvo. (Sic) $)^{77}$

Aunque la situación de una clase de comunidad espiritista no se conozca al detalle, con este caso en particular, se puede exponer el alcance, para un grupo pequeño de disidentes del catolicismo, lo que significó una batalla local entre sus prácticas espirituales y la posición de la Iglesia católica. Para ellos la excomunión, la exclusión social y, en el caso del Dr. Calvo, la muerte, fueron las implicaciones reales de ese conflicto.

\section{Círculo social de recepción del espiritismo en Medellín}

En Medellín el círculo de espiritistas estuvo conformado por familias, descendientes de mineros de oro, que sabían también francés, y que se dedicaron a oficios como la medicina, la fotografía, la escultura, la impresión (de periódicos como El Espectador) y la pedagogía. Este es el caso del círculo social y familiar de la familia de María Cano, Fidel Cano y Melitón Rodríguez.

Mario Arango, en su libro Masonería y partido liberal, afirmó que a partir de 1870 no solo se editaron en Antioquia las obras de Allan Kardec, sino que se difundieron sus doctrinas entre los círculos masónicos. En Medellín, a raíz de la publicación de la Imprenta Velásquez del libro de Allan Kardec, El espiritismo en

\footnotetext{
${ }^{76}$ «Soy católico, apostólico, romano y me someto en religión á lo que me ordene la Iglesia. Creo en el Símbolo apostólico, y por consiguiente creo en la Comunión de los Santos, que son los espiritus buenos.

Creo que la oración no es bien hecha, sino cuando se hace con fe, esperanza y caridad.

Creo que los feligreses tenemos la obligación perfecta de pagarles á los sacerdotes y curas de almas los derechos establecidos por la Iglesia para que puedan vivir con decencia.

Y creo que no debo continuar, como no continuo, enseñando nada en materia de religion, porque así me lo han mandado sacerdotes respetables; y por qué conozco que, no estando autorizado para ello, por medio del sacramento de la órden, procederia en esta enseñanza por autoridad propia, lo que me expondría á muchos errores, que ni quiero tenerlos en mi corazón, ni transmitirlos a generaciones venideras.

Sogamoso, marzo 12 de 1869.» (Sic) BNC, Miscelánea José Asunción Silva, 718, pieza 15, f. 21.

${ }^{77}$ BNC, Fondo Pineda, 851, pieza 213-3.
} 
Las imprentas, el liberalismo radical y comunicación con espíritus: divulgación de las...

su más simple expresión, la Iglesia católica respondió, a través de la Pastoral del excelentísimo Señor Doctor José Joaquín Isaza, obispo de Medellín y Antioquia, contra el espiritismo.

Para Patricia Londoño, entre 1850 y 1920 surgió una amplia gama de sociedades culturales ${ }^{78}$ como agrupaciones literarias, artísticas y teatrales, sociedades científicas y pedagógicas, asociaciones para el fomento cívico o moral, bandas o conjuntos musicales, orquestas y academias de "música culta". En estos espacios se dieron en Medellín los debates, las lecturas y las prácticas de sesiones espiritistas. No todos los personajes que acudían a estos grupos cultos eran espiritistas, pero hay que resaltar que el círculo social y familiar de la familia Rodríguez- Cano en Medellín influenció en gran medida el desarrollo cultural de la ciudad y algunos de ellos sí eran espiritistas practicantes.

Aunque la Iglesia católica trató por varios medios detener la propagación del espiritismo, este logró ser el medio por el cual los librepensadores reaccionaban frente al dogmatismo del clero antioqueño. En los círculos espiritistas de Antioquia figuraron personajes como Rodolfo Cano, padre de la líder sindical María Cano "La flor del trabajo", Melitón Rodríguez Roldán, padre de Melitón Rodríguez, al famoso fotógrafo, y Luis Zea Uribe, profesor de la facultad de medicina de la Universidad Nacional de Bogotá. ${ }^{79}$

El asunto del espiritismo durante el siglo XIX en Medellín se ha podido explicar en su mayor parte por el aporte de fuentes secundarias. A diferencia del caso de Bogotá, en Medellín se puede inferir acerca de quiénes eran espiritistas y comprender las relaciones familiares que los unían. También se pudieron encontrar publicaciones espiritistas publicadas por la Imprenta de El Espectador, pero lamentablemente los folletines, pasquines o cuadernos espiritistas publicados en Medellín no fueron encontrados.

En Medellín, el asunto del espiritismo "era una cosa del diablo", las autoridades eclesiásticas reaccionaron fuertemente contra quienes eran espiritistas, contra quienes distribuyeran, vendieran, leyeran o retuvieran el folletín El Espiritismo en su más simple expresión, y la excomunión fue la herramienta por medio de la cual la Iglesia católica persiguió y estigmatizó a espiritistas como Melitón Rodríguez Roldán y Rodolfo Cano, pedagogo, de quien la gente decía que «ihasta pacto con el Diablo debía tener!». ${ }^{80}$

\footnotetext{
${ }^{78}$ Véase cuadro 27. Fecha de fundación (por décadas) de las asociaciones devotas, benéficas y culturales en Antioquia, 1850-1930 en Patricia Londoño Vega, "Comentarios finales", en Religión, cultura y sociedad en Colombia. Medellín y Antioquia, 1850-1930 (México D.F: fondo de Cultura Económica, 2004), 342.

${ }^{79}$ De la cual se resalta el papel del médico liberal Luis Zea Uribe, fue espiritista, parlamentario, escritor, concejal de Bogotá, diputado de la Asamblea de Cundinamarca, Representante a la Cámara y miembro de la Academia Nacional de Medicina. Juan José Hoyos, "Los últimos momentos del general Uribe Uribe", en La pasión de contar. El periodismo narrativo en Colombia 1638-2000, (Medellín: Editorial Universidad de Antioquia, Hombre Nuevo Editoras, 2009), 398.

${ }^{80}$ Beatriz Helena Robledo, María Cano: La Virgen Roja (Bogotá: Penguin Random House Grupo
} 
A pesar de las condenas del clero antioqueño, el espiritismo fue practicado en Antioquia, y El Espectador le concedió al Centro Espiritista de Medellín varios espacios en su periódico, en los que se explicaba qué era el espiritismo y en el que los espiritistas se defendían con argumentos teológicos y filosóficos de los ataques de sus opositores. Fidel Cano (1854-1919), fundador de El Espectador era primo y amigo muy cercano de Rodolfo Cano (1887-1967), padre de La flor del trabajo la relación de ella con el espiritismo hace referencia al vínculo que tenía con su padre y con su hermana, La Rurra. A la muerte don Rodolfo, María:

[...] recorrió la casa tratando de descubrir a su padre en cada objeto. Sin lugar a duda, el lugar donde más estaba presente era la biblioteca. [...] Se detuvo a mirar la sección sobre espiritismo y ocultismo. Reconoció un libro sobre Swedenborg ${ }^{81}$, de quien Rodolfo hablaba con entusiasmo y lo presentaba como el padre del espiritismo. ${ }^{82}$

Según Helena Robledo, antes de las sesiones de espiritismo que realizaba Rodolfo Cano en su casa o en el taller del marmolero Melitón Rodríguez, se hacían debates sobre espiritismo, sobre el Libro de los Muertos de Egipto, las sociedades teosóficas, sobre médiums reconocidos, la masonería, los tratados cabalísticos, la filosofía hinduista y la Cábala entre otros temas.

Frente al espiritismo en Medellín hubo una especie de doble moral, ya que quienes asistían a las sesiones de espiritismo de la familia de Rodolfo Cano y de Melitón Rodríguez, eran católicos que solían arrepentirse de sus reuniones espiritistas los domingos en la misa. Además de esto, algunos de los personajes que atacaron al espiritismo acudían a la Rurra ${ }^{83}$ hermana de María Cano a invocar el espíritu de algún conocido, para encontrar entierros de oro o para aclarar malentendidos de familia. ${ }^{84}$

Por su parte, la sociedad católica antioqueña no era homogénea. Algo que demuestra esto es la acogida de prácticas esotéricas con raíces en el espiritismo, la simpatía por la masonería entre los sectores intelectuales liberales y la existencia de grupos de artistas y de bohemios marginales, manifestaciones que

Editorial, 2017), capítulo I, https://books.google.com.co/books?id=QZIrDwAAQBAJ\&pg=PT12\&lpg=P $\mathrm{T} 12 \& \mathrm{dq}=$ maria + cano + espiritismo\&source=bl\&ots=2brIh0U0zD\&sig=Q6fWHricTcc 39mF1IOVG-sMW$7 \mathrm{~g} \& \mathrm{hl}=\mathrm{es} \& \mathrm{sa}=\mathrm{X} \& \mathrm{ved}=0 \mathrm{ahUKEwio}$ pia4cjWAhVHKCYKHTGvANwQ6AEISTAG\#v=onepage\&q=mar ia $\% 20$ cano $\% 20$ espiritismo\&f $=$ false

${ }^{81}$ El sueco Emmanuel Swedenborg (1688-1772), hijo de un pastor luterano afirmaba que podía comunicarse con el espíritu de Lutero y que Dios en una visión le había revelado la naturaleza del mundo del más allá, en el que habitaban los espíritus. Su obra culmen en la que explica su concepción del mundo fue Del cielo y sus maravillas y el infierno. De las cosas oidas y vistas. Dufour, Alain, 2012. Las claves del espiritismo. Espíritus y médiums: comunicarse con el más allá. Barcelona: Editorial De Vecchi. https://books.google. com.co/books?id=P5m-ZqIOjJkC\&pg=PT25\&lpg=PT25\&dq=swedenborg+espiritismo\&source=bl\&ots= wxNRzrseWk\&sig=ed8Uni-ZnFzKWNIkn97x6B9th-g\&hl=es\&sa=X\&ved=0ahUKEwjUkPqlnuLXAhV Ff5AKHTVSCTEQ6AEIQjAD\#v=onepage \&q=swedenborg\%20espiritismo\&f=false

${ }^{82}$ Robledo, María Cano: La Virgen Roja, 31.

${ }^{83}$ Véase la película María Cano dirigida por Camila Lobo Guerrero. Ana María Arango, interpretó a la hermana de María Cano, La Rurra y en la película aparece leyendo la taza del chocolate de una vecina.

${ }^{84}$ Robledo, María Cano: La Virgen Roja, 33. 
muestran la resistencia hacia el modelo católico tradicional. En el contexto urbano de Antioquia, los artesanos fueron un grupo de gran importancia. Muchos de ellos apoyaron el desarrollo del arte, la fotografía, la arquitectura, la metalurgia, la talla, la ebanistería, la literatura, los periódicos y las revistas literarias. Entre los artesanos impactaron las ideas liberales, el espiritismo y el socialismo, ${ }^{85}$ ellos fueron herederos del liberalismo radical del siglo XIX y de los ideales de la Revolución francesa; con sus oficios artísticos, con sus adelantos tecnológicos y con sus ideas modernas criticaron el dominio de la Iglesia católica en Medellín desde la segunda mitad del siglo XIX hasta las tres primeras décadas del siglo XX. Por medio de la cultura, del arte y de sus oficios pudieron, los artesanos, situarse dentro del mundo intelectual a pesar de la bancarrota de sus familias o de sus excomuniones. Círculos sociales y familiares como el de la familia Rodríguez y la familia Cano (parientes entre ellos), convirtieron sus talleres en lugares de tertulia, en donde se leían textos prohibidos y prensa, se debatía sobre filosofía y política, se hacía música y se realizaban sesiones espiritistas. $^{86}$

\subsection{Debate espiritista en Medellín}

Se ha dicho que la sociedad antioqueña, debido a la influencia de la Iglesia católica, es “más tradicional”. Durante la segunda mitad del siglo XIX en esa región la Iglesia católica emprendió varias campañas en contra de intelectuales, artesanos, maestros y trabajadores con inclinaciones liberales, panfletarias, anticlericales o socialistas, ${ }^{87}$ pero a pesar de ello y del recrudecimiento de la situación económica para quienes perdían sus trabajos por sus inclinaciones políticas o religiosas, ideas como el espiritismo tuvieron su lugar.

La familia Rodríguez, relacionada con los Uribe, los Márquez, los Cano y los Zea, afectó en gran medida el desarrollo del mundo intelectual y artístico en Medellín. Con el auge económico producto de la minería en el nordeste antioqueño, los artesanos que trabajaban el oficio de la explotación minera en las décadas de 1830 a 1840 acaudalaron riquezas suficientes para enviar a sus hijos a estudiar a Europa. Estos primeros profesionales llevaron a Antioquia una nueva visión de la cultura y de la sociedad.

Así como se desarrolló el manejo de la madera, de las aguas, del trazado de rieles, de la utilización de la pólvora y del uso de los hornos en la explotación minera, se desarrolló también el mundo cultural que permitía el disfrute del arte en la sociedad antioqueña ${ }^{88}$. Ese fue el caso de la familia Rodríguez. Ramón Cipriano

\footnotetext{
${ }^{85}$ Catalina Reyes Cárdenas, “Grupos sociales y criminalidad. Medellín 1900-1930”, Revista de Extensión cultural 34-35 (1995): 73. http://www.bdigital.unal.edu.co/53568/1/catalinareyescardenas.1995.pdf (Consultado el 3 de enero, 2018)

${ }^{86}$ Reyes Cárdenas, "Grupos sociales y criminalidad”, 74.

${ }^{87}$ Patricia Londoño Vega, “Comentarios finales”, en Religión, cultura y sociedad en Colombia. Medellín y Antioquia, 1850-1930 (México D.F: fondo de Cultura Económica, 2004), 344.

${ }^{88}$ Juan Luis Mejía, "Mal de familia”, El Tiempo, 23 de noviembre de 1992. http://www.eltiempo.com/ archivo/documento/MAM-246121
} 
Rodríguez $^{89}$ fue minero y envió a su hijo Ricardo Rodríguez Roldán ${ }^{90}$ (1834-1912) a estudiar medicina a Francia. A la muerte de su padre le sobrevino al estudiante de medicina una crisis económica que lo impulsó a aprender en Francia el oficio de la talla en mármol y de la fotografía. A su regreso a Colombia, le enseñó ambos oficios a su hermano Melitón Rodríguez Roldán (padre) ${ }^{91}$, quien en compañía de algunos integrantes de su familia como el pintor Francisco Antonio Cano, conformaron el Taller de los Rodríguez. ${ }^{92}$

Con frecuencia, Melitón Rodríguez (padre) carecía de pedidos debido a los conflictos que tuvo con la Iglesia católica; de hecho, fue excomulgado por hacer sesiones de espiritismo en su taller y cultivar el estudio de las ciencias ocultas. ${ }^{93}$ Lo anterior lo llevó a vivir de la caridad pública, ya que los fieles católicos consideraban el espiritismo una cosa del diablo y además se les prohibía tener contacto con excomulgados; sin embargo, posteriormente con el cambio de autoridades clericales se le permitió volver a comulgar y retomar sus labores. ${ }^{94}$ En 1891 dos de sus hijos, Horacio Marino y Luis Melitón, en sociedad con Alberto Jaramillo, fundaron el Taller de Fotografía y Pintura de Rodríguez y Jaramillo.

Las manifestaciones culturales de Medellín se relacionan con los oficios de la familia Rodríguez. Las labores de esta familia trascendieron la minería y generaron los primeros movimientos artísticos antioqueños: la talla en mármol (relacionada con las honras fúnebres), la pintura, la fotografía, los grabados, la impresión de revistas literarias y el espiritismo, ${ }^{95}$ de hecho, tanto Horacio como Luis Melitón se formaron en familia con su pariente, el pintor Francisco Antonio Cano, ${ }^{96}$ del que aprendieron dibujo y pintura.

\footnotetext{
${ }^{89}$ Participó en la contienda entre liberales y conservadores en la Guerra civil de 1860 en Antioquia, de parte del ejército liberal Maribel Tabares Arboleda, "Melitón Rodríguez en Blanco y negro" (Tesis de Pregrado: Universidad de Antioquia, 2011), 145.

${ }^{90}$ No se encontraron fuentes que afirmaran el origen del contacto de la familia Rodríguez con el espiritismo, pero dado que Ricardo Rodríguez estudió en París en una época donde el espiritismo se encontraba de moda, es probable que fuera allí donde Ricardo Rodríguez haya conocido al espiritismo.

${ }^{91}$ Melitón Rodríguez Roldán, padre, fue también llamado “el viejo" o "El marmolero", su hijo Melitón Rodríguez Márquez fue el destacado fotógrafo antioqueño.

${ }^{92}$ Oficios como el de la marmolería se relacionaban con los oficios artesanos, se dedicaron los Rodríguez a las "artes mecánicas" es decir a los trabajos manuales. Maribel Tabares Arboleda, "Melitón Rodríguez en Blanco y negro" (Tesis de Pregrado: Universidad de Antioquia, 2011), 18.

${ }^{93}$ María Cano Robledo, La Virgen Roja, 26.

${ }^{94}$ Santiago Londoño Vélez, "Foto Rodríguez" en Testigo ocular. La fotografía en Antioquia, 1848-1950 (Medellín: Editorial Universidad de Antioquia, 2009), 116.

${ }^{95}$ Entrevista a Fernando Sierra, Medellín 9 de enero de 2010 citado por Maribel Tabares Arboleda, "Melitón Rodríguez en Blanco y negro" (Tesis de Pregrado: Universidad de Antioquia, 2011), 66.

${ }^{96}$ Francisco Antonio Cano se dirigía a estudiar pintura en Bogotá, pero debido a la guerra debió permanecer en Medellín fue acogido por su pariente, Melitón Rodríguez Roldán durante cinco años. Francisco Cano fue un pintor reconocido de Colombia, su obra más famosa es Horizontes de 1913, es una obra que representa a una pareja de colonos que hacen una parada en el camino que los lleva a donde finalmente se asentaran, ver obra en el link de la presente nota. Juan Luis Mejía Arango, "Horizontes, Francisco Antonio Caro" en Revista Arcadia http:/www.revistaarcadia.com/impresa/especial-arcadia-100/articulo/horizontesfrancisco-antonio-cano/35014 (Consultado el 3 de enero de 2018)
} 
Las imprentas, el liberalismo radical y comunicación con espíritus: divulgación de las...

Los Rodríguez tuvieron un taller que se convirtió en una clase de centro cultural en el que se discutía sobre literatura, el arte de la fotografía, el liberalismo, se arreglaban paraguas, se grababa sobre el vidrio se dictaban clases de dibujo y de pintura y se practicaba el espiritismo, creencia que le generó a los Rodríguez conflictos con las autoridades eclesiásticas, de hecho en los periódicos de la época en Medellín se encontraban frases como "Melitón Rodríguez tiene mármol pero no trabajo". ${ }^{97}$ Los oficios de esa familia relacionan a personajes como María Cano trabajó con el oficio de la fotografía en el taller de su primo Melitón, al respecto afirmó Ana María Cano:

En el taller de los Rodríguez, María Cano, la oradora, era mensajera y Carmen Luisa su hermana, retocadora de fotografía: un fogón de ideas de progreso que incluía ese saber invocar los espíritus iluminados para entender mejor el presente. La Rurra, como la llamaban a la mayor de las Canos, se sentaba en una banquetica y se alistaba a entrar en trance rezando el más hermoso padrenuestro $[\ldots]{ }^{98}$

El taller de los Rodríguez cambió de razón social, pero la empresa familiar se mantuvo activa hasta 1973. Actualmente el Fondo Fotográfico de la Fotografía Rodríguez cuenta con más de doscientos veinte mil negativos en vidrio sobre celulosa que datan de 1891 hasta 1934. En 1895 ese taller fue galardonado con la medalla en plata en el concurso de fotografía de la revista Luz y sombra de Nueva York. ${ }^{99}$ Melitón Rodríguez Márquez, cuando ya era un afamado fotógrafo en 1910, produjo algunas imágenes alegóricas similares a la fotografía espiritista. Por medio de la sobreimpresión de dos negativos en un positivo retocado mostró la idea de lo invisible en el mundo de la fotografía en Colombia. En esa fotografía un leñador afligido recibe el consuelo sobrenatural de un ángel protector:

Uno de los sitios más emblemáticos de Medellín está relacionado con la familia Rodríguez, El Cementerio San Pedro, fue fundado en 1842 por iniciativa de representantes de la élite antioqueña, es considerado actualmente como patrimonio cultural de la Nación. En él se puede apreciar el trabajo de Melitón Rodríguez Roldán, la lápida más antigua de autoría del espiritista data de $1866 .{ }^{100}$ En ese cementerio, que también ha sido llamado "Cementerio de los ricos", pudieron ser enterrados masones, liberales, espiritistas, socialistas y personajes que, en general, se destacaron por tener malas relaciones con la Iglesia católica. Desde 1845 se facilitaba el depósito de los restos mortuorios de personas con creencias religiosas distintas a la católica, ${ }^{101}$ allí fueron inhumados los restos de personajes como María Cano y su familia, Pedro Nel

\footnotetext{
${ }^{97}$ Juan Luis Mejía, "El taller de los Rodríguez" https://rodriguezuribe.co/documents/TallerRodriguez OCR\%5B1\%5D.pdf (consultado el 28 de noviembre de 2017)

${ }^{98}$ Ana María Cano, "Masonería”, 105.

${ }^{99}$ Santiago Londoño, "Foto Rodríguez" ,119.

${ }^{100}$ Véase foto de la lápida en la tesis de Maribel Tabares Arboleda, "Melitón Rodríguez en Blanco y negro", página 39.

${ }^{101}$ Autor corporativo. El cementerio de San Pedro: El rito de la memoria. 160 años. Medellín: Colección Crónicas del Regreso, 2002, 107. Citado por Maribel Tabares Arboleda, "Melitón Rodríguez en Blanco y negro", página 46.
} 
Ospina, Pepe Sierra, Jorge Isaacs, Fidel Cano, ${ }^{102}$ y Cipriano Rodríguez, el abuelo de Melitón Rodríguez. ${ }^{103}$

\subsection{Producción del discurso espiritista en Medellín. Imprenta de El Espectador}

Un hecho para resaltar en la historia del espiritismo en Medellín es que en El Espectador se le concedió a este movimiento un espacio de divulgación generoso en las cuestiones espiritistas. Fueron varios los artículos que pretendían divulgar y defender las doctrinas espiritistas del Centro Espiritista de Medellín en los que con el pseudónimo de Veritas se firma la autoría de los artículos.

A diferencia de José Benito Gaitán de Bogotá, Fidel Cano el fundador de El Espectador no era espiritista. Si bien tuvo roces con la Iglesia, era considerado un verdadero cristiano que le profesaba su fe al Niño Jesús. En algunas ocasiones en las que su periódico estuvo clausurado, para sostener a su familia Fidel Cano editaba y vendía novenas de santos. ${ }^{104}$ En 1888 tuvo su mayor pleito con la Iglesia católica, ya que se preparaban las bodas de oro sacerdotales del Papa León XIII, y en El Espectador se publicó un artículo de Mario Arana en el que se criticaba el contraste entre la fastuosidad y el lujo de dicha celebración, con la pobreza y humildad predicadas por Cristo. Por este asunto, el obispo Bernardo Herrera prohibió a los católicos de su diócesis, bajo pena de pecado mortal, "leer, comunicar, transmitir, conservar, o de cualquier manera auxiliar al periódico titulado El Espectador". ${ }^{105}$

De alguna manera, Fidel Cano tuvo contacto con las doctrinas espiritistas. Las fuentes primarias y secundarias consultadas permiten especular acerca de la relación de Fidel Cano con el movimiento espiritista. Se sabe que su familia estaba relacionada con la práctica espiritista en Medellín: Fidel Cano era primo de Rodolfo Cano, ${ }^{106}$ padre de María Cano, Rodolfo era docente y llegó a ser el director de la escuela Normal de Antioquia, en tiempos de gobierno liberal. Rodolfo Cano y su familia fueron espiritistas, de hecho, María Ramona Antonia La Rurra, una de sus hijas llegó ser una médium reconocida y muy solicitada en Medellín. ${ }^{107}$

\footnotetext{
${ }^{102}$ Administración del Cementerio Museo San Pedro, "San Pedro: el cementerio museo que cuenta la historia de Medellín" http://reddebibliotecas.org.co/diario/san-pedro-el-cementerio-museo-que-cuenta-lahistoria-de-medellin (Consultado el 3 de enero de 2018)

${ }^{103}$ Juan Luis Mejía, "El taller de los Rodríguez”, 4.

${ }^{104}$ Luis Fernando Múnera, "El espiritismo en El Espectador”, en Fidel Cano. Su vida, su obra y su tiempo, (Medellín: Imprenta Universidad de Antioquia, 2005), 166.

${ }^{105}$ Héctor Muñoz, "El lio con el obispo Herrera”, en Fidel Cano patriarca del periodismo, (Bogotá: Editora Guadalupe Ltda., 2007), 62.

${ }^{106}$ Rodolfo Cano se dedicó a labores intelectuales toda su vida, era ante todo un ilustrado, leía y traducía obras en francés e inglés

${ }^{107}$ Luis Fernando Múnera, "Rodolfo Cano", en Fidel Cano. Su vida, su obra y su tiempo, (Medellín: Imprenta Universidad de Antioquia, 2005), 52.
} 
El círculo de difusión de espiritismo en Medellín no se redujo únicamente a las publicaciones espiritistas de El Espectador, de hecho hubo una publicación de la Imprenta de Velázquez y Compañía El espiritismo en su más simple expresión, escrito en francés por M. Allan Kardec que según Natalia Jabonero, bibliotecaria de la Biblioteca Nacional de Colombia no se encuentra en ninguna biblioteca, es decir en algún momento el texto estuvo en poder de esa biblioteca pero por alguna razón hoy en día solamente hay registro de su existencia en catálogo de la BNC. ${ }^{108}$

En Medellín, según Luis Fernando Múnera, la doctrina espiritista se aceptaba y se promovía por grupos de cristianos, lo que se puede comprobar en el artículo Espiritismo "La ola sube", publicado en El Espectador el 17 de junio de 1887, donde los espiritistas tratan de explicar qué es el espiritismo: "Si unidos marchamos los espiritistas y si en el interior de nuestros hogares, con el fin inocente de hacer nuestros estudios y oraciones, unidos nos encuentran, nuestras reuniones no tienen nada de secreto, en nada se parecen a la Logia, y es esta la razón por la cual damos al viento de la publicidad nuestras creencias". 109

Una de las ideas más controversiales del espiritismo en Medellín visibles en las fuentes primarias es la explicación de que los espiritistas, aunque creen en el evangelio, y en Cristo, no conciben su figura como una divinidad, es decir, Cristo, aunque sí es el más elevado de los espíritus tal como se ha apreciado en otras publicaciones espiritistas, no es una divinidad. En el artículo anteriormente mencionado los espiritistas explicaron:

El evangelio es nuestra norma [...] Creemos en el espíritu, creemos también en la divina misión de los enviados, pero no en la divinidad de sus personas ${ }^{110}$ [...]"La definición de la vida y de su objeto, de su misión, es la base de toda religión posible: para vosotros es la culpa original, es el retorno a Dios por la fe en un ser divino descendido a la tierra y sacrificad para expiarla; para nosotros es la imperfección de la criatura finita, es su posibilidad de corregirse gradualmente por virtud otorgada a todos, con nuestras obras, con el sacrificio de nuestro egoísmo a favor del común mejoramiento[...]Vosotros creéis en la divinidad de Jesús, y nosotros miramos como origen de esa creencia la necesidad del tiempo en que ella sola podía afirmar la combatida victoria del Cristianismo[...]Nosotros veneramos en Jesús el fundador de una época emancipadora del individuo; el Apóstol de la unidad de las leyes, más ampliamente comprendidas que en los tiempo anteriores; el Profeta de la identidad de las almas, y nos postramos ante Él como ante el hombre que amó más entre los que conocemos,[...] pero no abismamos el hombre en el Dios, no lo elevamos a donde no podemos ya alcanzarle, queremos antes amarle hermano mejor nuestro, que adorarle y temerle juez inexorable y dominador intolerante de lo futuro. ${ }^{11}$

\footnotetext{
${ }^{108}$ Natalia Jabonero, entrevistada por la autora, Bogotá 2 de enero, 2018.

${ }^{109}$ Firmado por Veritas, "El espiritismo "La ola sube"”, El Espectador [Medellín] 17 de junio, 1887. B.N.C, Hemeroteca, VFDU1- 501.

${ }^{110}$ Cursivas por la autora

${ }^{111}$ Veritas, "El espiritismo "La ola sube””, El Espectador [Medellín] 17 de junio, 1887
} 
Con el reconocimiento de la figura de Cristo como un profeta o un espíritu elevado, se desvirtúa también el asunto de la trinidad, que, por ejemplo, en Parte moral del evangelio fue explicada por el espiritismo como un concepto muy anticuado para nada adecuado al siglo XIX. Estas afirmaciones son un duro golpe para el catolicismo y no es de extrañar que los espiritistas, aunque podían causar curiosidad como lo afirma Múnera, en Medellín debían ser perseguidos y la Iglesia debía ser radical en el rechazo al movimiento espiritista y a sus integrantes.

En el número del 10 de mayo de 1887, en la sección Mesa Revuelta del periódico El Espectador, hay un artículo titulado Espiritismo que fue escrito por don Fidel Cano:

En la sección Remitidos de esta hoja publicamos hoy la respuesta que da el Centro Espiritista de esta ciudad a un artículo que contra sus doctrinas apareció hace pocos días en La voz Antioquia. No somos espiritistas, pero creemos que toda doctrina tiene derecho a libre discusión, como al aire todo ser viviente; y tanto por esto cuanto porque la respuesta del Centro espiritista va en una sección de cuyas opiniones no son responsables, según costumbre, los redactores de periódicos, le damos cabida en nuestras columnas. Agrégase a estas consideraciones la de que en periódico que acogió el ataque contra los espiritistas, les ha negado espacio para defenderse. (sic) ${ }^{112}$

No se sabe si el espacio que se le daba al espiritismo en el periódico se debía a un interés personal de Fidel Cano, o si allegados a él, aparte de su primo y amigo Rodolfo Cano, influenciaron la cultura de Medellín al punto de que el tema espiritista debía ser tratado por el periódico liberal. Son varias y en algunas ocasiones extensas las publicaciones que sobre el espiritismo aparecen en ese periódico, además La Imprenta El Espectador publicó otros textos sobre el tema, un ejemplo de ello es un texto de 1889 de 8 páginas de 21 centímetros titulado $A$ los espiritistas. En ese texto, referenciado en el apartado Producción de textos espiritistas las directrices del movimiento espiritista en ese congreso aconsejaban:

A. El estudio de la doctrina espírita B. Su propaganda por todo medio lícito C. Su realización constante por la práctica de las virtudes públicas y privadas [...] E. El esfuerzo constante de propagar la religión laica en todas las esferas de la sociedad F. Tratar de obtener la libertad absoluta de pensamiento y la enseñanza integral de ambos sexos. [...] Extinguir el odio de clases [...] abolir las fronteras con ayuda de la palabra y la prensa. Establecer un movimiento de ideas con el fin de modificar los sistemas civiles y penales de cada país $[\ldots] .^{113}$

Esta publicación redactada por el Centro Espiritista de Medellín tiene como objetivo confirmar sus creencias, validarlas, darles la característica de

\footnotetext{
${ }_{112}$ Fidel Cano, "Espiritismo", El Espectador [Medellín], 10 de mayo, 1887, Número 13, 3. B.N.C, Hemeroteca, VFDU1- 501.

${ }^{113}$ Con el asunto de la modificación de los sistemas penales se puede ver la intención del espiritismo de corriente española de querer ser un movimiento con intereses de modificar los sistemas políticos antiliberales. A los espiritistas, BNC, Miscelánea J.A.S, Pieza 6. 713.
} 
movimiento internacional científico. En ella se afirma que Colombia contó con una representación, hecho que no se puede constatar por medio de otra fuente primaria que así lo compruebe, pero es interesante resaltar que entre lo que el congreso espiritista aconsejaba, aparece el objetivo de abolir las fronteras con ayuda de la palabra y la prensa, es decir el espiritismo sí proponía a sus creyentes que tenían como misión difundir del espiritismo por medios como la prensa.

Así como en Bogotá, el espiritismo en Medellín se encuentra relacionado con quienes poseían los medios de producción de textos. Los debates espiritistas y el círculo social que ejercía estas prácticas alternas de espiritualidad en la ciudad de Medellín pudieron ser reconstruidos con mayor claridad con el aporte de fuentes secundarias, en la ciudad antioqueña, el espiritismo se relaciona también con una élite intelectual compuesta por impresores, fotógrafos, pedagogos, escultores y médicos, que influenciada por el liberalismo pudo poner en circulación las críticas a la posición del clero en la sociedad y a las creencias tradicionales del catolicismo.

El proceso de dominación que proviene del monopolio de la palabra ${ }^{114}$ se rompe con personajes que permitieron que el discurso espiritista, entendido como un acontecimiento, pudiera volverse asequible, al menos para quien sabía leer y quien podía comprar un periódico. Ese fue el lugar de producción del espiritismo en Bogotá, con el impresor José Benito Gaitán, y en Medellín, con la Imprenta del Espectador, con ese acontecimiento se rompe lo que Martín Barbero designa como una "cultura de la sumisión y del silencio", ${ }^{115}$ las imprentas de Gaitán y la de El Espectador fueron el ejemplo de cómo los medios se convirtieron en los "púlpitos modernos" por medio de los cuales, hubo un nuevo proceso de comunicación.

Las prácticas espiritistas en Bogotá y en Medellín, tuvieron dos facetas: por un lado, se ha comprobado por la existencia de fuentes primarias, el papel de las imprentas de Gaitán y de El Espectador en la producción de textos espiritistas en forma de revistas, periódicos, artículos y folletos; y por otro, que es lo que sugieren las fuentes secundarias, pudo haber existido un factor de transmisión oral del espiritismo, esto es lo que puede especularse acerca del círculo social de la familia Rodríguez en Medellín, en el que se realizaban tertulias y debates no solo acerca de temas literarios y políticos, sino de temas como el ocultismo, la teosofía, la filosofía y el espiritismo.

El proceso comunicativo del espiritismo no se reduce únicamente a lo explicado anteriormente, también hubo una clase de dialogo entre la Iglesia Católica y el espiritismo. En el caso de Medellín los conflictos entre el espiritismo y la Iglesia son más evidentes que en el caso de Bogotá, y pudieron ser comprobados por medio de un folleto producido por la Diócesis de Antioquia, el estudio del caso de Medellín sirve como una ejemplo para introducir el asunto de la existencia de un conflicto entre la Iglesia católica y el espiritismo, ya que en esta parte de la historia del espiritismo en

\footnotetext{
114 Jesús Martín Barbero, "Elementos para una teoría crítica del discurso", en Comunicación masiva: discurso y poder. (Quito: Ediciones Ciespal, 2015), 59.

${ }^{115}$ Barbero, "Elementos para una teoría crítica del discurso", 61.
} 
Colombia, hay dos elementos, por un lado, la relación, aunque en este caso tangencial, entre el espiritismo y quienes tenían los medios para publicar textos, y en segundo lugar, se muestra que la Iglesia católica respondió y atacó el espiritismo, con lo que se hace visible que hubo un conflicto entre el catolicismo y esta propuesta espiritual alternativa a la religión institucionalizada.

\section{Conclusiones}

A pesar de que el discurso científico en el siglo XIX estaba en el camino de probar que el hombre estaba hecho de materia, el hombre moderno no podía desprenderse de siglos de construcción de pensamiento religioso dominado por el cristianismo. En Colombia, durante el siglo XIX, los debates intelectuales se alimentaron de la incertidumbre acerca de la naturaleza del alma, del interés por lo oculto, de la fascinación por la ciencia, del romanticismo, de los debates políticos y de la posibilidad de criticar a instituciones religiosas como la Iglesia católica.

El espiritismo como un movimiento espiritual, no como una religión, surgió en un contexto en que el mundo cambiante se replanteaba cómo, en medio de la industrialización, de los valores de la Ilustración y de la ciencia, los individuos podían acercarse a Dios. El espiritismo fue mucho más que una comunidad o movimiento espiritual que se reunía a hacer sesiones para contactar con los muertos; el espiritismo no fue, en ningún sentido, un simple movimiento se superstición popular, fue un conjunto de prácticas que, basado en muchas corrientes de pensamiento, consolidó un discurso que le permitió integrar la ciencia, la espiritualidad y el liberalismo, en un corpus fascinante de folletos, revistas y periódicos.

Afirmar si los espíritus entraban o no en contacto con los asistentes a las reuniones espiritistas, si podían estos ser o no fotografiados, si el fenómeno de las mesas giratorias era o no una farsa, no fueron objetivos de esta investigación. Lo que se pretendió las prácticas de quiénes, en Colombia, estuvieron relacionados con el círculo espiritista; con ello se pudo dilucidar que a este círculo pertenecieron personajes de una élite intelectual, o nueva burguesía compuesta por liberales, personajes relacionados con el gremio de artesanos, con el mundo del arte, de la fotografía, de la escultura y de las imprentas. El espiritismo pudo satisfacer en ellos, en cierta medida, las necesidades, las inquietudes y las disconformidades propias del hombre ilustrado de fines del siglo XIX.

Los representantes de este movimiento, no solo en Colombia sino a nivel mundial, rehusaron que el cuerpo de doctrinas espiritistas fuera reconocido como una religión, pues para ellos las religiones ortodoxas habían conducido a la humanidad al círculo devastador de la guerra, del hambre, de la ignorancia y de la falta de progreso, para ellos lo verdaderamente importante fue su proceso subjetivo de espiritualidad.

Si bien el espiritismo tiene una influencia innegable del cristianismo, este movimiento es más allegado al protestantismo en cuanto a la elaboración de un discurso crítico frente a la depravación que les representaba el catolicismo. En 
Colombia, ser espiritista marcaba una diferencia con el creyente tradicional, los dogmas espiritistas diferenciaban radicalmente a sus adeptos de quienes tuvieran un pensamiento conservador y clerical, mediante la lectura y la reproducción del mensaje espiritista.

Hubo una idea errónea acerca de que los liberales eran ateos, y nada más alejado de la realidad, el espiritismo, que era una idea muy controversial y radical, fue uno de los ejemplos de un anticatolicismo radical que no era ateo. Pero por más hereje que fuera el discurso espiritista no significó en ningún momento que se desligara completamente de las creencias religiosas y espirituales propias de su época: asuntos como el evangelio, la caridad y la moral formaban parte del gran constructo de dogmas en los que se basó el espiritismo. Sin embargo, es preciso tener en cuenta que hubo ciertos dogmas del cristianismo que este movimiento rechazaba; el más controversial de ellos, es que, para los espiritistas, Jesús era el más elevado de los espíritus, por lo tanto, su figura no es la de una divinidad.

Un aspecto fundamental en la historia del espiritismo en Colombia es que el círculo social al que pertenecían los espiritistas estaba relacionado con una industria que fue el eje central de la producción del discurso espiritista local: la imprenta. Fueron personajes como los liberales José Benito Gaitán y Fidel Cano, quienes le dedicaron al espiritismo un lugar de enunciación, fueron ellos, los que rompieron con el circuito de comunicación tradicional, que era sumiso al poder estatal y clerical, fueron ellos quienes dejaron en sus textos, las pistas por medio de las cuáles hay evidencias de la existencia del espiritismo en Colombia durante el siglo XIX.

La imprenta fue el lugar de producción del discurso espiritista en Colombia, fueron los allegados al mundo de las letras, del arte, del liberalismo y de la fotografía, quienes se atrevieron a incursionar en el mundo de los espíritus, con irreverencia frente al catolicismo intransigente y con la reelaboración de un discurso incendiario que planteaba una lectura nueva y fresca del evangelio. Personajes como José Benito Gaitán reprodujeron el mensaje espiritista francés, lo adecuaron al contexto en el que vivían; fueron los espiritistas quienes se atrevieron no solo a criticar el papel de la Iglesia católica en Colombia, sino a quitarle el carácter sagrado a una espiritualidad que para ellos era anticuada; ellos se atrevieron a publicar textos en los que claramente se le quitaba el aura de sagrados e intocables a los representantes de la Iglesia; ellos se atrevieron a afirmar que Cristo era el más elevado de los espíritus, pero no una divinidad; ellos desacralizaron en el siglo XIX algunos de los fundamentos en los que se cimentó la sociedad colombiana. Quienes se relacionaron con la producción de textos espiritistas como José Benito Gaitán y Fidel Cano, contaban, en el siglo XIX, en medio de todas las dificultades que el oficio de impresor representaba, con una fuente de poder: la imprenta, que representaba los medios tecnológicos y de producción de textos que posteriormente, se conocería como los medios de comunicación masiva.

El mensaje espiritista, inspirado por el liberalismo, por la idea de la democracia, de la igualdad, de la fraternidad, de la caridad y de la búsqueda del ejercicio de una ciudadanía intelectualmente enriquecida, y espiritualmente superior, 
fue transformado y reinterpretado por los espiritistas colombianos. Ese mensaje ya no necesitaba de un dirigente eclesiástico para ser difundido pues en el siglo XIX fueron los periódicos, las revistas y los folletos los nuevos púlpitos, mediante los cuales el mensaje de esta nueva espiritualidad de la Nueva Revelación podía llegarle a la población.

Si bien el periodo que, en teoría, debería haber erradicado las prácticas espiritistas en Colombia sería la Hegemonía Conservadora, se encontraron fuentes que demuestran que pese a la persecución, a la exclusión social, a la excomunión y a la publicación de textos en los que la Iglesia católica rechazaba y condenaba la práctica del espiritismo, esta disidencia logró sobrevivir en el siglo XIX, incluso en el siglo XX hubo personajes, también de élite intelectual y política que defendían y que publicaron obras espiritistas. Tal es el caso del doctor Luis Zea Uribe, un médico liberal, espiritista y político que, entre otras cosas fue famoso por haberle brindado los cuidados médicos a Rafaél Uribe Uribe cuando fue asesinado en 1914, Zea Uribe publicó en París en 1923 Mirando al misterio: Contribución al estudio de los fenómenos medianímicos y sus proyecciones sobre el problema moral y religioso, una de las obras espiritistas más extensas publicadas por un espiritista colombiano. Siendo así ni las ideas propias de la Regeneración, ni el poder de la Hegemonía Conservadora, lograron impedir que la comunicación con espíritus y que las ideas anticatólicas propias del espiritismo siguieran siendo parte de la escena política y pública en Colombia, tanto así que al día de hoy en Colombia los espiritistas se encuentran afiliados por medio de diferentes sociedades espiritistas y son ellos quienes en 2018, para conmemorar los 150 años de la publicación de Parte Moral del Evangelio, en Australia imprimieron una reedición con ortografía modernizada de dicho folleto.

Imprentas como la de Gaitán y la de Cano, fueron en el siglo XIX, los medios de comunicación por los cuales el espiritismo fue divulgado en una época en la que la noción de comunicación de masas no había surgido, fueron personajes pertenecientes a una élite ilustrada quienes divulgaron el mensaje espiritista.

Son varias las preguntas que quedan abiertas respecto al espiritismo en Colombia, sería muy interesante conocer qué fue de este movimiento en el siglo XX, qué transformaciones tuvo y cuáles son las relaciones con el espiritismo colombiano actual. Para ello ya no solo bastaría un estudio histórico sino un estudio antropológico que permita dilucidar cómo este movimiento puede ser comprendido hoy en día.

\section{Bibliografía}

\section{Fuentes primarias}

Conferencia sobre el espiritismo (Sogamoso) Biblioteca Nacional de Colombia, Miscelánea José Asunción Silva 718, pieza15. 
Las imprentas, el liberalismo radical y comunicación con espiritus: divulgación de las...

El espiritismo en Sogamoso, o sea su refutación (Duitama) Biblioteca Nacional de Colombia, Miscelánea José Asunción Silva, 846, pieza 2.

Papel Periódico Ilustrado, Número 29 del 28 de octubre de 1882. Citado por Higuera, "La imprenta en Colombia.

Psychis ó Estudios del Alma Humana (Bogotá) Biblioteca Nacional de Colombia, Prensa, VFDU1-1662

Una esplicación al público (Sogamoso) Biblioteca Nacional de Colombia, Fondo Pineda, 851, pieza 213.

\section{Fuentes de archivo}

Archivo: A los espiritistas (Medellín) 1899. En Biblioteca Nacional de Colombia (B.N.C) Miscelánea José Asunción Silva, 713.

Biblioteca Luis Ángel Arango, Miscelánea 1193, colección Eduardo Nieto Calderón. Doctrina Espiritista-cristiana o mi profesion de fe moral y relijiosa (sic) Disponible en formato digital en http://babel.banrepcultural.org/cdm/singleitem/ collection/p17054coll10/id/866

Biblioteca Luis Ángel Arango (BLAA) Colección de documentos en la Biblioteca Virtual de la Biblioteca Luis Ángel Arango Miscelánea 683. El minero de la verdad. Entrega I. El espiritismo en su mas simple espresion por M. Allan Kardec" (sic) Disponible en formato digital en http://www.banrepcultural.org/sites/default/ files/brblaa304638.pdf

Biblioteca Nacional de Colombia, (BNC), Miscelánea José Asunción Silva, 424, Pieza 12. Disponible en versión digital en http://catalogoenlinea.bibliotecanacional.gov. co/client/es_ES/search/asset/75043

Biblioteca Nacional de Colombia, (BNC), Miscelánea José Asunción Silva, 15, pieza 5. Disponible en versión digital en http://catalogoenlinea.bibliotecanacional.gov. co/client/es_ES/search/asset/63043

Biblioteca Nacional de Colombia, Miscelánea José Asunción Silva, 424, Pieza 12. Disponible en formato http://catalogoenlinea.bibliotecanacional.gov.co/client/ es_ES/search/asset/75043

\section{Prensa}

El Espectador (Medellín) 1887.

El Espectador (Medellín) 1889.

La Nueva Idea (Bogotá) 1873. 


\section{Fuentes secundarias}

\section{Libros}

Cacua Prada, Antonio. Historia del periodismo colombiano. Bogotá: Editorial Fondo Rotatorio Policía Nacional, 1968.

Conan Doyle, Arthur. El país de la bruma. Novela espiritista. Madrid: Ediciones Oriente, 1929.

Cristina, María Teresa. "María: Las vicisitudes de un texto". Jorge Isaacs Obras Completas, ed. María Teresa Cristina. Bogotá: Universidad Externado de Colombia.

Dufour, Alain. Las claves del espiritismo. Espíritus y médiums: comunicarse con el más allá. Barcelona: Editorial De Vecchi, 2012.

Gil, Rubén Periodismo: historia y teoría. t.I Barcelona: Editorial CLIE, 1993.

Higuera, Tarcisio. La imprenta en Colombia, 1737-1970. Bogotá: Instituto Nacional de Provisiones, 1970.

IDEA. El cementerio de San Pedro: El rito de la memoria. 160 años. Medellín: Colección Crónicas del Regreso, 2002.

Isaacs, Jorge. María. Bogotá: 1868. Disponible en versión digital Biblioteca Nacional de Colombia, (BNC), Colección de recursos digitales. http://catalogoenlinea. bibliotecanacional.gov.co/client/es_ES/search/asset/138300

Kardec, Allan. ¿Qué es el espiritismo? Introducción al conocimiento del mundo invisible por las manifestaciones de los espíritus. Pontificia Universidad Javeriana. Traducida por la Sociedad Barcelonesa propagadora del espiritismo. Barcelona: Sociedad Barcelonesa propagadora del espiritismo, 1871.

Krause, Enrique. Francisco I. Madero. El místico de la libertad. México D.F: Fondo de cultura económica, 1897.

Loaiza Cano, Gilberto. Manuel Ancizar y su época. Biografía de un politico hispanoamericano del siglo XIX, Medellín: Fondo Editorial Universidad Eafit, 2004.

Ospina, Joaquín. Diccionario Biográfico y bibliográfico de Colombia. Bogotá: Editorial Águila, 1937.

Otero Buitrago, Nancy. Tomás Cipriano de Mosquera. Análisis de su correspondencia como fuente historiográfica y mecanismo de poder. 1845-1878. Cali: Universidad del Valle, 2015. 
Las imprentas, el liberalismo radical y comunicación con espiritus: divulgación de las...

Robledo, Beatriz Helena. María Cano: La Virgen Roja. Bogotá: Penguin Random House Grupo Editorial, 2017.

Romero, José Luis. Latinoamérica. Las ciudades y las ideas. Buenos Aires: Siglo XXI ,2001.

Skinner, Quentin. Lenguaje politica e historia. Buenos Aires: Universidad Nacional de Quilme, 2007.

Swedenborg, Emmanuel. Del cielo y sus maravillas y el infierno. De las cosas oidas $y$ vistas, s.f.

Toro Jaramillo, Iván Darío. El pensamiento de los católicos colombianos. En el debate ideológico de la "crisis de medio siglo" (1850-1900). Medellín, Departamento de publicaciones fundación Universitaria Luis Amigo, 2005.

\section{Capítulos de libros}

Barbero, Jesús Martín. “Elementos para una teoría crítica del discurso”. Comunicación masiva: discurso y poder. Quito: Ediciones Ciespal, 2015.

Barbero, Jesús Martín. "Ni pueblo ni clases". De los medios a las mediaciones. México D.F: Editorial Gustavo Gili, S.A, 1987.

Cano, Ana María. "Masonería", en Medellín secreto. En cinco reportajes sobre clausura, masonería, locura y sexo aparece una ciudad oculta. Medellín: Ediciones la Hoja Mes S.A, 1995.

De Certeau, Michael. "Introducción general". La invención de lo cotidiano 1. Artes de hacer. México D.F: Instituto Tecnológico y de Estudios Superiores de Occidente, A.C, 2000.

Hoyos, Juan José. "El tipógrafo más antiguo de Bogotá". La pasión de contar. El periodismo narrativo en Colombia 1638-2000. Medellín: Editorial Universidad de Antioquia, Hombre Nuevo Editoras, 2009.

Hoyos, Juan José. "Los últimos momentos del general Uribe Uribe". La pasión de contar. El periodismo narrativo en Colombia 1638-2000. Medellín: Editorial Universidad de Antioquia, Hombre Nuevo Editoras, 2009.

Hugo, Víctor. "Paréntesis". Los Miserables, Parte Segunda, Libro séptimo. Traducido por Nemesio Fernández- Cuesta. España: Biblok Book Export, S.L, 2017.

Loaiza Cano, Gilberto. "Poder letrado, ensayos sobre historia intelectual de Colombia Siglos XIX y XX”. Cultura Popular. Cali: Programa editorial Universidad del Valle, 2014. 
Londoño Vega, Patricia. "Comentarios finales". Religión, cultura y sociedad en Colombia. Medellín y Antioquia, 1850-1930. México D.F: Fondo de Cultura Económica, 2004.

Londoño Vélez, Santiago. "Foto Rodríguez". Testigo ocular. La fotografía en Antioquia, 1848-1950. Medellín: Editorial Universidad de Antioquia, 2009.

Mancera, Ana María. “150 años de la publicación de un texto espiritista en Bogotá: Parte Moral del evangelio, explicado por los espíritus perfectos" Pieza del mes. Biblioteca Nacional de Colombia. http://bibliotecanacional.gov.co/es-co/ actividades/Publicaciones-sobre-el-patrimonio/Pieza-del-mes/detalle-piezadel-mes?titulo=150\%20años $\% 20 \mathrm{de} \% 201 \mathrm{a} \% 20$ publicación $\% 20 \mathrm{de} \% 20$ un $\% 20$ texto $\% 20$ espiritista $\% 20$ en $\% 20$ Bogotá:\%20Parte $\% 20$ moral $\% 20 \mathrm{del} \% 20$ evanjelio,\%20explicado\%20por\%20los\%20esp\%C3\%ADritus\%20perfectos, 2018.

Múnera, Luis Fernando. "El espiritismo en El Espectador". Fidel Cano. Su vida, su obra y su tiempo. Medellín: Imprenta Universidad de Antioquia, 2005.

Muñoz, Héctor. "El lio con el obispo Herrera”. Fidel Cano patriarca del periodismo. Bogotá: Editora Guadalupe Ltda., 2007.

\section{Tesis, ponencias, documentos y otros}

Camargo Rojas, Lucía. "Las rutas del impreso: el folletín, la novela por entregas y la sociedad letrada bogotana (1850-1860)". Tesis de pregrado, Pontificia Universidad Javeriana, 2008.

Jabonero, Natalia. Entrevista realizada por Ana María M.R. Bogotá, Colombia, 2 de enero, Jesús Martín Barbero, "Elementos para una teoría crítica del discurso", en Comunicación masiva: discurso y poder. (Quito: Ediciones Ciespal, 2015), 59.

Lobo Guerrero, Camila. "María Cano", 1990. (Película 106 minutos).

Mancera, Ana María. "Historia intelectual del espiritismo en Colombia. (1868-1889).” Tesis inédita de pregrado en Historia, Pontificia Universidad Javeriana, 2018.

Mejía, Juan Luis. "Mal de familia”. El Tiempo. 23 de noviembre de 1992. http://www. eltiempo.com/archivo/documento/MAM-246121

Tabares Arboleda, Maribel. "Melitón Rodríguez en Blanco y negro" Tesis inédita de Pregrado en Historia: Universidad de Antioquia, 2011.

\section{Artículos de revistas}

Cárdenas Ayala, Elisa «El fin de una era: Pío IX y el Syllabus». Historia Mexicana, El colegio de México 65, no. 2 (2015):739. 
Las imprentas, el liberalismo radical y comunicación con espiritus: divulgación de las...

de Roux, Rodolfo R. "La romanización de la Iglesia católica en América Latina: una estrategia de larga duración", Pro-Posições 25, no. 1 (2014): 31-48.

Flórez, Rubén Darío "Lectores de bibliotecas vs una biblioteca de lector". Entornos, 30.1. (2017): 24-42.

García Ortiz, Laureano "Las viejas librerías de Bogotá”. Discursos académicos. Biblioteca de la Presidencia de la República. 21-39. http://www.bdigital.unal.edu. co/397/ (2017)

Horta, Gerard "Espiritismo y carisma. Orígenes carismáticos del liderazgo en el movimiento espiritista europeo del siglo XIX". Gazeta de antropología 20. 10. (2004): 12-29.

Loaiza Cano, Gilberto. "Cultura popular y espiritismo (Colombia, siglo XIX)". Historia y espacio No. 32 (2009): 7-22.

Mayor Moya, Alberto "24 horas en la vida de dos artesanos de 1914". Revista colombiana de sociología-Nueva Serie 2, no. 2 (1993-1994): 48-62.

Reyes Cárdenas, Catalina. “Grupos sociales y criminalidad. Medellín 1900-1930”, Revista de Extensión cultural. 34. (1995) http://www.bdigital.unal.edu.co/53568/1/ catalinareyescardenas.1995.pdf (Consultado el 3 de enero, 2018). 